\title{
Manganese redox cycling in Lake Imandra: impact on nitrogen and the trace metal sediment record
}

\section{J. Ingri ${ }^{1}$, L. Pekka ${ }^{1}$, V. Dauvalter ${ }^{2}$, I. Rodushkin ${ }^{3}$, and E. Peinerud ${ }^{3}$}

${ }^{1}$ Division of Applied geology, Luleå University of technology. 97187 Luleå, Sweden ${ }^{2}$ Institute of Problems of Industrial ecology of the North, Kola Scientific Center, Russian academy of Sciences, ul, Fersmana 14, Apatity, Murmansk oblast 184 200, Russia ${ }^{3}$ ALS Laboratory Group, ALS Scandinavia AB, Aurorum 10, 97775 Luleå, Sweden

Received: 11 November 2010 - Accepted: 17 November 2010 - Published: 11 January 2011 Correspondence to: J. Ingri (johan.ingri@ltu.se)

Published by Copernicus Publications on behalf of the European Geosciences Union.

\section{Manganese redox cycling in Lake Imandra \\ J. Ingri et al.}

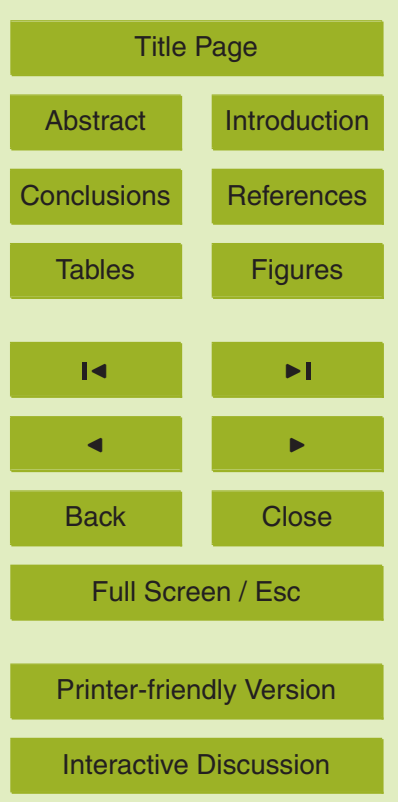




\section{Abstract}

Sediment and water samples from the mine-polluted Yokostrovskaya basin in Lake Imandra have been analysed. Three major processes have influenced the accumulation and distribution of metals in the sediment: (1) Development of the apatite5 nepheline and the sulfide ore mining industries. (2) Secondary formation of sulphides in the upper sediment column. (3) Redox cycling of $\mathrm{Mn}$ in the surface sediment and in the bottom water.

This study demonstrate the dominant role of the Mn redox cycling in controlling distribution of several major and trace elements, especially during the winter stratification period. Mn oxides act as a major scavenger and carrier for the non-detrital fraction of $\mathrm{Al}, \mathrm{Ca}, \mathrm{K}, \mathrm{Mg}, \mathrm{P}, \mathrm{Ba}, \mathrm{Co}, \mathrm{Cu}, \mathrm{Ni}, \mathrm{Mo}$ and $\mathrm{Zn}$ in the bottom water. Aluminium, $\mathrm{Ca}, \mathrm{K}, \mathrm{Mg}$, $\mathrm{P}, \mathrm{Cu}, \mathrm{Ni}$ and $\mathrm{Zn}$ are mainly sorbed at the surface of the particulate $\mathrm{Mn}$ phase, while $\mathrm{Ba}$ and Mo form a phase (or inner sphere complex) with $\mathrm{Mn}$. Co is associated with the $\mathrm{Mn}$-rich phase, probably by oxidation of $\mathrm{Co}$ (II) to a trivalent state by the particulate

15 Mn surface. Formation and dissolution of Mn particles most likely also control anoxic ammonium oxidation to nitrate and reduction of nitrate to $\mathrm{N}_{2}$.

It is shown that secondary sulphides in Lake Imandra sediments are fed with trace metals primarily scavenged from the dissolved phase in the water column. This enrichment process, driven by the Mn-redox cycle, therefore changes the sediment record by the transfer of a dissolved pollution signal to the particulate sediment record, thus making it more complicated to trace direct influence of particles from different pollution sources.

\section{Introduction}

Although lake sediments provide environmental archives for trace metal pollution history (Birch et al., 1996; Yang et al., 2002), the fate of deposited metals in sediments and their post-depositional mobility is related to the nature and extent of biogeochemical
BGD

8, 273-321, 2011

\section{Manganese redox cycling in Lake Imandra \\ J. Ingri et al.}

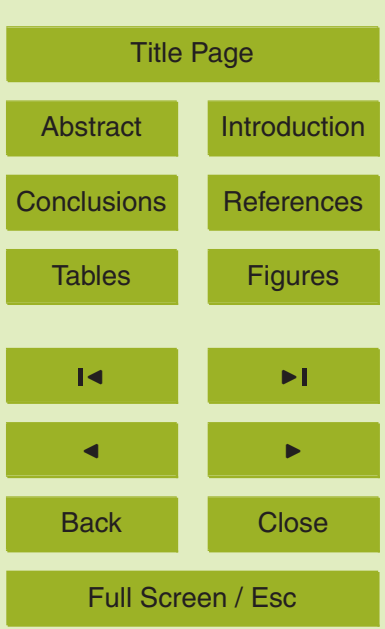

Printer-friendly Version

Interactive Discussion 
transformations in the zone formed between oxic and sulfidic conditions. Hence, secondary processes in the upper sediment alter the environmental archive. Considerable attention has been paid to the mechanisms controlling the distribution of trace metals in different geochemical phases in sediments and their remobilization and mobility across 5 the oxic-sulfidic boundary (e.g., Murray, 1987; Salomons et al., 1987; Huerta-Diaz et al., 1998; Brown et al., 2000; Saulnier and Mucci, 2000; Bilali et al., 2002; Yang et al., 2002; Otero et al., 2003; Belzile et al., 2004; Stockdale et al., 2010).

Organic matter decomposition in bottom water and sediment induce chemical transformations in the porewater and solid phase of lake sediments utilizing a characteristic 10 sequence of oxidants, i.e., $\mathrm{O}_{2}, \mathrm{NO}_{3}^{-}, \mathrm{Mn}(\mathrm{IV}), \mathrm{Fe}(\mathrm{III})$, and $\mathrm{SO}_{4}^{2-}$ (Froelich et al., 1979; Davison, 1993). The high specific area of amorphous or poorly crystallized $\mathrm{Fe}$ and Mn oxyhydroxides provides an efficient scavenging pathway for metals in oxic waters (Balistrieri and Murray, 1982; Davison, 1993). It has been shown that in early stages of formation manganese oxides contain many vacancies (Petkov et al., 2009). These vaments regulate the flux of trace elements into the overlying water (Douglas and Adeney, 2000). Under reducing conditions these Fe(III) and Mn(IV) oxyhydroxides dissolve and scavenged trace metals are released. These ions will then migrate by diffusion along a concentration gradient upwards through the water column or downwards in the sediment (Davison, 1993). The upward diffusion will eventually lead to the reprecipitation of $\mathrm{Fe}$ and $\mathrm{Mn}$ oxyhydroxides at near-surface layer, whereas the downward diffusion can lead to the precipitation of iron sulphides $\left(\mathrm{FeS}\right.$ and $\left.\mathrm{FeS}_{2}\right)$ and rhodochrosite $\left(\mathrm{MnCO}_{3}\right)$ or a dolomite-type Ca-Mn carbonate in deeper layers of the sediment (Mucci, 1988; Belzile and Tessier, 1990; Davison, 1993; Friedl et al., 1997). The presence of sulphides is considered to be one of the major factors controlling the immobilization of metals in sediments, as most of divalent metals form insoluble sulphides or coprecipitate and adsorb on iron sulphides (Morse and Luther, 1999; Martin et al., 2001; Naylor et al., 2004). Sulphide is formed by microbially mediated reduction of sulphates in anoxic sediments, or as a direct product of organic matter decomposition (Morse
BGD

$8,273-321,2011$

\section{Manganese redox cycling in Lake Imandra}

J. Ingri et al.

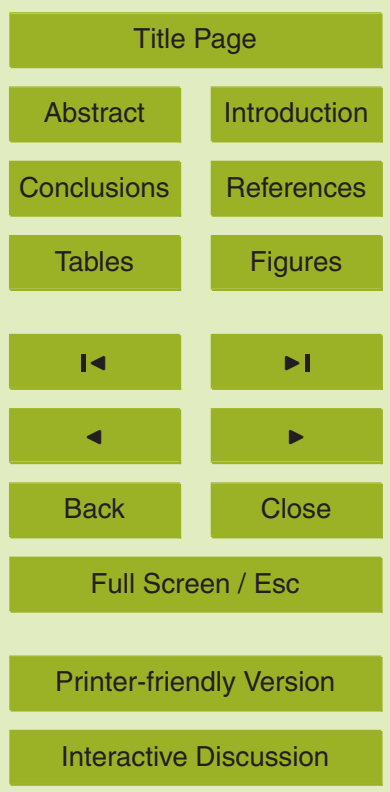


and Luther, 1999; Neal et al., 2001). Iron sulphide is the major sulphide component found in most freshwater and marine sediments and numerous studies have reported its strong affinity for a number of trace metals (e.g., Huerta-Diaz et al., 1998; Neal et al., 2001). Hence, the accumulating trace metal sediment record is not only influenced 5 by primary particles from industrial activities, but also by secondary sulphides forming in the sediment.

The complex redox barrier formed between oxic and sulfidic environments, regulates the flux of elements between these two environments. Manganese is a key element regulating the flux across the interface and the deposition of metal sulphides 10 e.g., Jørgensen and Nelson (2004). Studies in a number of lakes have pointed out the importance of $\mathrm{Mn}$ oxides in transporting a variety of trace metals, including $\mathrm{Cd}$, Co, $\mathrm{Cu}, \mathrm{Ni}, \mathrm{Zn}$ (Balistrieri et al., 1994; Green et al., 1998, 2004; Shacat et al., 2004), Pb (Balistrieri et al., 1994; Canfield et al., 1995), As, Cr, Mo, V (Balistrieri et al., 1992), REE (De Carlo and Green, 2002, Shacat et al., 2004), Sr and Ba (Sugiyama et al., 1992) and major elements (Sholkovitz and Copland, 1982)

The expansion of the mining industries, and subsequent pollution history, within the Lake Imandra drainage area, Russian Kola Peninsula, can be divided into five periods. How these five periods have influenced the historical sediment metal record in the Yokostrovskaya Imandra is discussed in this study. The historical record is directly coupled to processes in the water column and surface sediment. This study is focused on geochemical cycling of $\mathrm{Mn}$ and its influence on the distribution, transport and mobility of a suite of major and trace elements in Lake Imandra.

\section{Study area}

Lake Imandra, the largest water body on the Russian Kola Peninsula, is located in the 25
BGD

$8,273-321,2011$

\section{Manganese redox cycling in Lake Imandra \\ J. Ingri et al.}

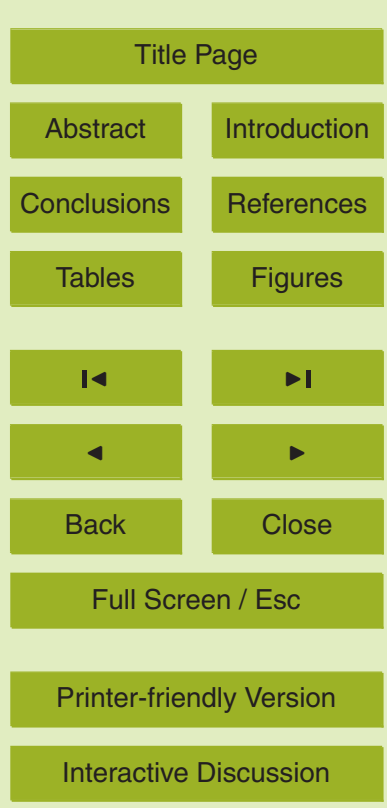


lake is about 2 years (Moiseenko and Yakovlev, 1990). The Niva River is the only outflow of the lake and drains into the White Sea (Moisenko et al., 2002). Lake Imandra consists of three individual pools (the Bolshaya, Yokostrovskaya and Babinskaya Imandras) connected with each other by narrow straits (Fig. 1).

$5 \quad$ Intensive industrial activities close to Lake Imandra during the past 70 years have deteriorated the oxygen conditions in the lake and increased the total dissolved solids concentration, from 24 to $80 \mathrm{mgl}^{-1}$. Lake Imandra, in its natural state, was a typical soft water lake. The natural status of the lake was characterized by low concentration of total dissolved solids (TDS) of 20-30 mg ${ }^{-1}: \mathrm{Mg}^{2+}\left(0.5-1.3 \mathrm{mgl}^{-1}\right)+\mathrm{Ca}^{2+}$ $10 \quad\left(1.6-4.0 \mathrm{mgl}^{-1}\right)+\left(\mathrm{Na}^{+}+\mathrm{K}^{+}\right)\left(2.5-7.5 \mathrm{mgl}^{-1}\right)+\mathrm{HCO}_{3}^{-}\left(13-18 \mathrm{mgl}^{-1}\right)+\mathrm{SO}_{4}^{2-}\left(1-3 \mathrm{mgl}^{-1}\right)$ $+\mathrm{Cl}^{-}\left(1.4-1.8 \mathrm{mgl}^{-1}\right)+\mathrm{SiO}_{2 \mathrm{aq}}\left(0.6-1.3 \mathrm{mg} \mathrm{I}^{-1}\right.$ ), and $\mathrm{pH}$ 6.4-7.2 (Moiseenko, 2002). Furthermore, a high biogenic load on the lake's drainage area during several decades (municipal and industrial wastewaters, stock farming and agricultural fields) has resulted in a pronounced anthropogenic eutrophication of the lake, especially of the Bolshaya 15 Imandra pool (Moiseenko et al., 2002). The natural oligotrophic state is changing to mesotrophic and in some zones to a eutrophic state (Moiseenko and Yakovlev, 1990). As a result, anoxic conditions are observed near the bottom during the ice-covered period, while the epilimnion is well oxygenated all year round due to discharging of numerous ice-free mountain rivers into the lake (Moiseenko and Yakovlev, 1990).

20 The major polluters within the drainage area, the Cu-Ni smelter Severonikel in Monchegorsk, the open-pit Fe mine and ore concentration plant in Olenegorsk and the apatite-nepheline mine and concentration plant "Apatit" in Apatity, are all concentrated along the Bolshaya Imandra basin discharging improperly treated mine- and process waters directly into the lake (Fig. 1). Mine- and process waters of the Severonikel $25 \mathrm{Cu}-\mathrm{Ni}$ smelter contain high concentrations of dissolved and particulate $\mathrm{S}, \mathrm{Ni}$ and $\mathrm{Cu}$ (Moiseenko et al., 1996, 2002). Dauvalter et al. (2000) estimated that the total input of $\mathrm{Ni}$ and $\mathrm{Cu}$ with wastewater discharges and atmospheric emissions from Severonikel into Lake Imandra during the period 1988-1991 were 138.7 and 39.1 tonnes, respectively. Wastewater discharges accounted for $89 \%$ of the Ni total influx and for $12 \%$ of

\section{BGD}

8, 273-321, 2011

\section{Manganese redox cycling in Lake Imandra \\ J. Ingri et al.}

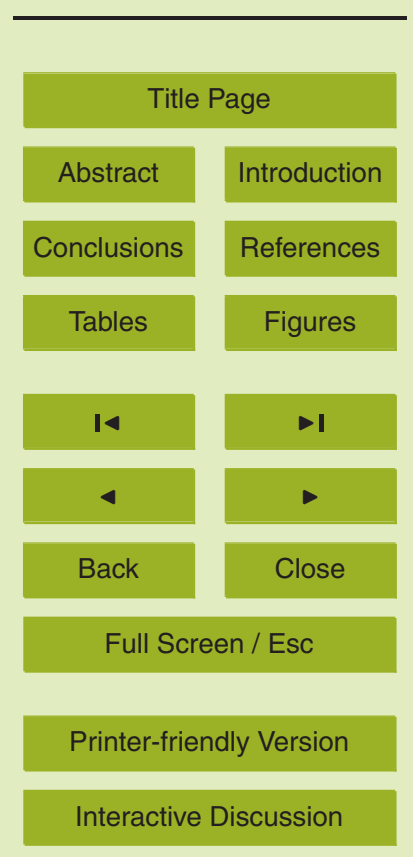

Interactive Discussion 
the $\mathrm{Cu}$ total influx, while input from the drainage area accounted for $88 \%$ of $\mathrm{Cu}$ and for $11 \%$ of Ni total influx into the lake (Dauvalter et al., 2000).

Other polluters discharging into Bolshaya Imandra are Olenegorsk Mechanical Plant (wastewater discharge of $100 \mathrm{~m}^{3} /$ day, pollutants are suspended matter, phenols, flota5 tion agents, $\mathrm{Cu}$ and $\mathrm{Zn}$ ), and industrial and domestic effluents from urban communities Monchegorsk, Kirovsk and Apatity (more than 350000 people) (Moiseenko et al., 2002; Moiseenko and Yakovlev, 1990).

\section{Sampling and analytical methods}

\subsection{Sampling}

10 The sample station (Fig. 1) was located $5 \mathrm{~km}$ south of the strait connecting the Bolshaya and the Yokostrovskaya pools of Lake Imandra $\left(67^{\circ} 34^{\prime} \mathrm{N}, 32^{\circ} 59^{\prime} \mathrm{E}\right)$. This part of the lake reflects the influence of an integrated transient mine- and process water inflow from the major polluters (Fig. 1). At the sampling point, the water depth is $30 \mathrm{~m}$. The sampling was performed on three occasions, in April, August and October 1995. In

15 April, the sampling of dissolved $(<0.45 \mu \mathrm{m})$ and suspended solids $(>0.45 \mu \mathrm{m})$ from 18 sampling levels within the water column, together with a sediment core, was performed from the ice. In August and October, water was sampled from 8 levels within the water column from a boat.

Water temperature, $\mathrm{pH}$, conductivity and dissolved $\mathrm{O}_{2}$ were measured in situ using 20 a Hydrolab $^{\circledR}$ (Surveyor II) water quality probe. The probe was calibrated before and after each day in the field. Samples of water were collected using silicone tubing lowered below the water surface to a fixed depth. Water was then pumped up into acid-cleaned 25 I plastic cans using a portable Masterflex ${ }^{\circledR}$ peristaltic pump and Tecalan ${ }^{\circledR}$ tubing. In order to separate dissolved $(<0.45 \mu \mathrm{m})$ and suspended $(>0.45 \mu \mathrm{m})$ solids in the sam25 ples, the water was filtered through $0.45 \mu \mathrm{m}$ Millipore ${ }^{\circledR}$ cellulose membrane filters with
BGD

$8,273-321,2011$

\section{Manganese redox cycling in Lake Imandra \\ J. Ingri et al.}

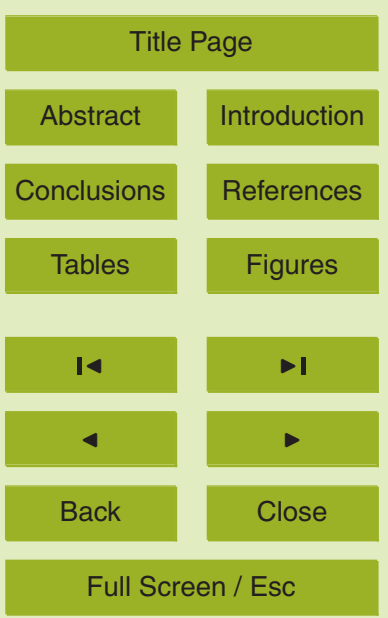

Printer-friendly Version

Interactive Discussion 
a diameter of $142 \mathrm{~mm}$, mounted in Geotech ${ }^{\circledR}$ polycarbonate filter holders and collected in acid-washed polyethylene bottles. The filtration of water samples was performed directly in the field in April and in the laboratory within one hour after sampling in August and October. The filters were leached in 5\% acetic acid before sampling. Four filters 5 were used for each sample: two filters for determination of major elements, and two filters for the determination of trace elements. The total volume of filtered water for each pair of filters was measured. Filters with the suspended material were frozen awaiting sample preparation and analysis. The water samples were stored in the refrigerator at $4{ }^{\circ} \mathrm{C}$ until analysis. For analysis of particulate $\mathrm{C}$, water was filtered through Whatman ${ }^{\circledR}$ GF/F filters (pore size $0.7 \mu \mathrm{m}$ ) that had been combusted in $500^{\circ} \mathrm{C}$ for $1 \mathrm{~h}$.

A sediment core was sampled using a modified Kajak gravity corer with a Plexiglas tube with inner diameter of $44 \mathrm{~mm}$ (Blomqvist and Abrahamsson, 1985). The core was sliced in $1 \mathrm{~cm}$ sections, placed in plastic boxes and stored at $4{ }^{\circ} \mathrm{C}$ awaiting further sample preparation and analysis. Pore water samples were extracted from the $0-2 \mathrm{~cm}$, $0.45 \mu \mathrm{m}$ membrane filters according the same filtration procedure as for water samples.

\subsection{Analytical methods}

Analyses of samples (dissolved and suspended solids, sediment and porewater) from the sampling occasion in April were carried out at ALS in Luleå, Sweden, while the samples from the sampling occasions in August and October were analyzed at the INEP laboratory of the Kola Science Centre in Apatity. The analytical methods employed are described below.

\subsubsection{Water samples}

Filtered $\mathrm{Ca}, \mathrm{K}, \mathrm{Mg}, \mathrm{Na}$ and $\mathrm{Si}$ from the water column were analyzed by FAAS (Perkin25

Elmer 460 ) technique. Filtered Fe and Ni were analyzed by GFAAS (Perkin-Elmer
BGD

8, 273-321, 2011

\section{Manganese redox cycling in Lake Imandra \\ J. Ingri et al.}

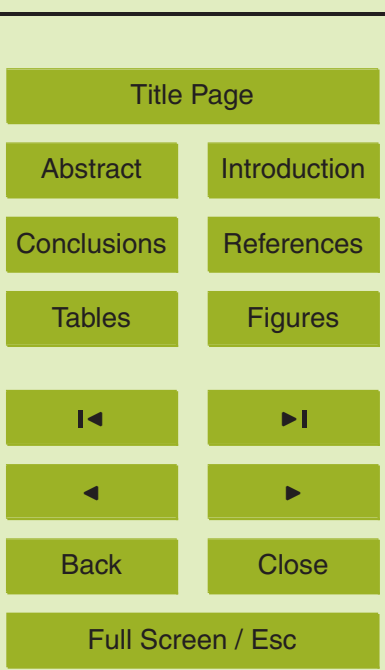

Printer-friendly Version

Interactive Discussion 
5000) technique. Al, Mn, Ba, Co, $\mathrm{Cu}, \mathrm{Mo}, \mathrm{Pb}$ and $\mathrm{Zn}$ were analyzed by ICP-QMS (VG Plasma Quad 2) at Analytica and by GFAAS technique at the INEP laboratory. Sulphate was analyzed by liquid chromatography (Millipore Waters 430). Alkalinity was analyzed using the Gran titration method. Phosphate, $\mathrm{NO}_{2}^{-}-\mathrm{N}+\mathrm{NO}_{3}^{-}-\mathrm{N}$ (referred to as $\mathrm{NO}_{3}^{-}$) and 5 total nitrogen concentrations were determined using colorimetric methods. Pore water samples were analyzed in the same manner as water samples from the water column in April.

\subsubsection{Suspended solids}

Four filters were used for each sample. The suspended solids sample preparation and 10 analytical procedures were performed according the method described by Ödman et al. (1999). Two filters were wet-ashed in $14 \mathrm{M} \mathrm{HNO}_{3}$ in Pt crucibles, and then dry-ashed at $550{ }^{\circ} \mathrm{C}$. The ash was then fused with $\mathrm{LiBO}_{2}$ in graphite crucibles at $1000^{\circ} \mathrm{C}$. The bead thus formed was dissolved in $\mathrm{HNO}_{3}$ and $\mathrm{Al}, \mathrm{Ca}, \mathrm{Mg}, \mathrm{K}, \mathrm{Na}$, Si and $\mathrm{Ti}$ were analyzed in solution by ICP-AES technique (model ARL 3580). Two remaining filters were digested in $8 \mathrm{ml}$ of $14 \mathrm{M}$ supra pure $\mathrm{HNO}_{3}$ in Teflon bombs and heated in a microwave oven. An addition of $1 \mathrm{ml} 30 \% \mathrm{H}_{2} \mathrm{O}_{2}$ completed the oxidation of organic matter. Analysis of $\mathrm{Fe}$, $\mathrm{Mn}, \mathrm{S}, \mathrm{Ba}, \mathrm{Cu}, \mathrm{Mo}, \mathrm{Pb}$ and $\mathrm{Zn}$ was performed with ICP-AES (ARL 3580) and analysis of Co and Ni with ICP-QMS (VG Plasma Quad 2) techniques. The suspended load was determined by collecting suspended matter on pre-weighed Millipore polyvinylidene 20 fluoride membrane filters. After sampling, the filters were dried at $50{ }^{\circ} \mathrm{C}$ and weighed. The particulate $C$ analyses were performed using an elemental analyzer (EA 1108).

\subsubsection{Sediment samples}

The preparation of the sediment samples and analytical procedures were performed according the method described by Burman et al. (1978). Subsamples, $0.125 \mathrm{~g}$, of the dried and homogenized sediment were fused with $\mathrm{LiBO}_{2}$ at $1000^{\circ} \mathrm{C}$. The bead thus formed was dissolved in $0.7 \mathrm{M} \mathrm{HNO}_{3}$. Analyses of major elements were performed with
BGD

$8,273-321,2011$

\section{Manganese redox cycling in Lake Imandra \\ J. Ingri et al.}

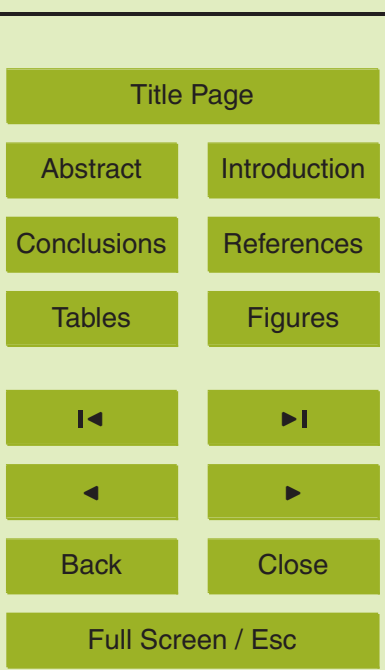

Printer-friendly Version

Interactive Discussion 
ICP-AES (ARL 3560, ARL 3580). For analysis of $S$ and trace metals, $0.5 \mathrm{~g}$ sediment was digested in $10 \mathrm{ml} 7 \mathrm{M} \mathrm{HNO}_{3}$ in Teflon bombs and heated in a microwave oven. After centrifugation and dilution, elements were determined by ICP-AES (ARL 3560, ARL 3580) and ICP-QMS (VG Plasma Quad 2). Carbon and N were determined with 5 an elemental analyzer (EA 1108).

\section{Results}

\subsection{The sediment record in Lake Imandra}

Based on the history of the mining industries outlined above, the pollution history of Lake Imandra can be divided into five periods: (I) Pre-industrial period, before 1930; II)

10 Early industrial period, from 1930 to 1955; (III) Industrial period with no treatment facilities or recirculation systems, from 1955 to 1975; (IV) Period of maximum production volumes in the mining industries, between 1980 and 1990, and (V) Period of declined production and, accordingly, declined anthropogenic load to the lake, from 1993 to the present.

\subsubsection{Pre-industrial period (I)}

Below $14 \mathrm{~cm}$, the chemical composition of the sediment shows little variation, with low and constant metal concentrations (Figs. 2, 3, 4, 5 and 6). This sediment section most likely reflects the pre-industrial period, before 1930 .

\subsubsection{Early industrial period (II)}

20 The first signs of disturbed sediment appear at $14 \mathrm{~cm}$. A lowered $\mathrm{Ca} / \mathrm{Ti}, \mathrm{Ba} / \mathrm{Ti}, \mathrm{Al} / \mathrm{Ti}$, $\mathrm{Fe} / \mathrm{Ti}, \mathrm{K} / \mathrm{Ti}, \mathrm{Mg} / \mathrm{Ti}, \mathrm{Si} / \mathrm{Ti}$ and increased $\mathrm{Mo} / \mathrm{Ti}$ ratios are observed at this depth (Figs. 2, 3,4 and 5). From $14 \mathrm{~cm}$ up to $10.5 \mathrm{~cm}$ there is a continuous decrease in the C/P ratio (Fig. 2b). The significant decrease in the C/P ratio, from around 230 below $14 \mathrm{~cm}$, to
BGD

$8,273-321,2011$

\section{Manganese redox cycling in Lake Imandra \\ J. Ingri et al.}

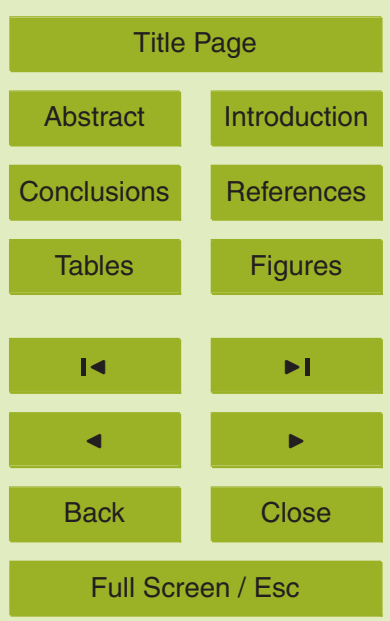

Printer-friendly Version

Interactive Discussion 
around 35 at $10 \mathrm{~cm}$, indicates that the $P$ increase during this interval is not primarily related to changes in biological production, but related to an inflow of P-rich particulate material. The decrease in the C/P ratio most likely reflects the onset (1930) and early development of apatite mining (1930-1955).

\section{4.1.3 Industrial period with no treatment facilities or recirculation systems (III)}

Between 10.5 and $6.5 \mathrm{~cm}$ the concentrations of $\mathrm{P}, \mathrm{Ca}, \mathrm{Sr}$ and $\mathrm{Ba}$ (Fig. 2) increase dramatically (for $P, 23$ times higher than below $14 \mathrm{~cm}$ ) and reach a maximum between 6.5 and $7.5 \mathrm{~cm}$. In contrast to $\mathrm{P}, \mathrm{Sr}$ and $\mathrm{Ba}$ the $\mathrm{Ca} / \mathrm{Ti}$ ratio shows two peaks, at $9.5 \mathrm{~cm}$ and at $7.5 \mathrm{~cm}$. The increase between 10.5 and $6.5 \mathrm{~cm}$ probably reflects the maximum expansion period of the apatite mining industry (1955-1975). In the beginning of this period, at $9.5 \mathrm{~cm}$, transient peaks for $\mathrm{Al} / \mathrm{Ti}, \mathrm{Fe} / \mathrm{Ti}, \mathrm{K} / \mathrm{Ti}$ and $\mathrm{Na} / \mathrm{Ti}$ are observed (Fig. 3). In contrast to the other major elements both $\mathrm{Mg}$ and $\mathrm{Si}$ show a decrease throughout zone III (Fig. 4).

The sediment profiles for As, Cd, Co, Mo, Pb and Zn (Fig. 5) all show the same drastic increase between $10.5 \mathrm{~cm}$ and $9 \mathrm{~cm}$, correlating with Al-Fe-Na-Ca-K within zone III (Fig. 3). The transient peaks of both major and trace elements are most likely related to the industrial activities around Apatity, possibly linked to the construction of a series of large settling dams at the apatite complex between 1955-1965 and the opening of new open pits (Moiseenko et al., 1996, 2002). The increase in Mn from $10.5 \mathrm{~cm}$ to $9 \mathrm{~cm}$ 20 (Fig. 6a) is also most likely related to the expansion of the apatite mining. However, influence from the ore concentration plant in Olenegorsk, which started in 1955, on the $\mathrm{Mn}$ and Fe increase during this period cannot be excluded. At this complex, magnetite ores are mined and treated, and $\mathrm{Mn}$ and $\mathrm{Fe}$ are the major pollutants emanating from this industry (Moiseenko et al., 2000).

25 The $\mathrm{Cu}$ and Ni sediment profiles (Fig. 6) are completely different from those of the other trace metals. In the upper $10 \mathrm{~cm}$ of the sediment column $\mathrm{Cu}$ and $\mathrm{Ni}$ are well correlated $\left(R^{2}=0.95, p<0.0001\right)$ and show a continuous increase in the concentrations throughout zone III (Fig. 6). The influence from the apatite mining appears to be small
BGD

8, 273-321, 2011

\section{Manganese redox cycling in Lake Imandra \\ J. Ingri et al.}

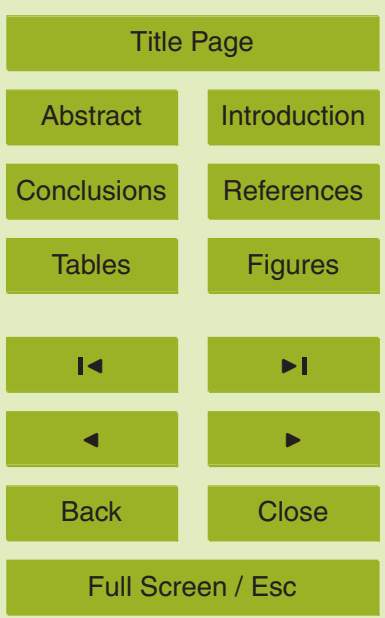

Printer-friendly Version

Interactive Discussion 
for these elements in comparison with other sources. The enhanced concentrations of $\mathrm{Ni}$ and $\mathrm{Cu}$ in this zone most likely reflect the influence of the Severonikel Cu-Ni smelter in Monchegorsk. The increasing concentrations of particulate $S$ from the same depth (Fig. 6) support this assumption. In 1960, after reconstruction and expansion, 5 the production volume increased 2.7 times at this site (Moiseenko et al., 2002). The increase of $\mathrm{Cu}, \mathrm{Ni}$ and $\mathrm{S}$ up to $6.5 \mathrm{~cm}$ is most likely mainly due to deposition of allogenic (detrital) sulphide particles.

The concentrations of $\mathrm{P}, \mathrm{Ca}$ (and also $\mathrm{Sr}$ and $\mathrm{Ba}$ ) decreases above $7.5 \mathrm{~cm}$, but are stabilized above $6 \mathrm{~cm}$ at higher values than the pre-industrial concentrations (Fig. 2). 10 Concentrations of $\mathrm{Al}, \mathrm{K}, \mathrm{Na}, \mathrm{Mg}$ and $\mathrm{Si}$ in the upper $5 \mathrm{~cm}$, on the other hand, show significantly lower values than the background (Figs. 3 and 4). Consequently, the particulate material that deposits in Yokostrovskaya today is more influenced by apatite related elements than the pre-industrial material. The decrease in $\mathrm{P}, \mathrm{Ca}, \mathrm{Sr}$ and $\mathrm{Ba}$ between $7.5 \mathrm{~cm}$ and $5 \mathrm{~cm}$ most likely reflects the effects of treatment facilities and recirculation systems installed in the late-1970s, as the production volumes continued to increase until the beginning of the 1990s.

The large decrease in $C$ concentration between $14 \mathrm{~cm}$ and $9.5 \mathrm{~cm}$ (Fig. 3), indicates that $\mathrm{C}$ was diluted by increased inorganic particulate influx related to the period of the early apatite mining expansion. Above $9 \mathrm{~cm}$, the $C$ concentration steadily increases towards the sediment surface and reaches values up to $8700 \mathrm{~m} \mathrm{~mol} \mathrm{~kg}^{-1}$. The concentration of $C$ in the surface sediment (upper $2 \mathrm{~cm}$ ) is almost 2 times higher compared with a pre-industrial $C$ concentration of $\approx 5200 \mathrm{~m} \mathrm{~mol} \mathrm{~kg}^{-1}$ below $14 \mathrm{~cm}$ depth. The trophic status of Lake Imandra is currently changing from oligotrophic to mesotrophic, in some areas even to eutrophic (Moiseenko et al., 1996), which may explain the increasing C

\subsubsection{Zone of active secondary sulphide formation (IV)}

A significant increase in the particulate $S$ concentration is seen between $10.5 \mathrm{~cm}$ and $2 \mathrm{~cm}$ with a peak around $5 \mathrm{~cm}$ (Fig. 6). The zone between $2 \mathrm{~cm}$ and $6.5 \mathrm{~cm}$ probably

BGD

$8,273-321,2011$

\section{Manganese redox cycling in Lake Imandra \\ J. Ingri et al.}

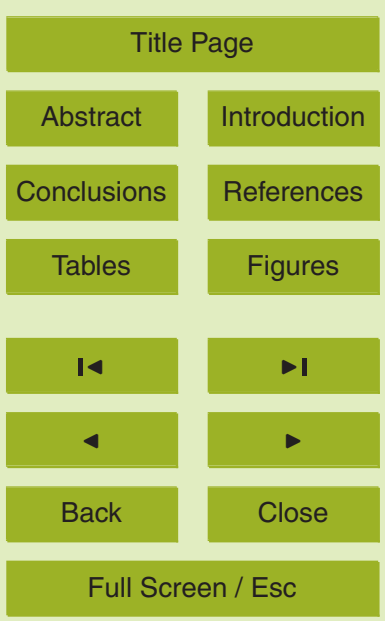

Printer-friendly Version

Interactive Discussion 
reflects precipitation of secondary sulphides coupled to $\mathrm{SO}_{4}^{2-}$ reduction. The anthropogenic supply of sulphur has dramatically increased the concentration of sulphate in the water column (from 1-3 mg/l to $20-30 \mathrm{mg} / \mathrm{l}$, Moiseenko, 2002) causing a higher $\mathrm{SO}_{4}^{2-}$ accumulation and reduction in the sediment. The pore water profile (Fig. 6b)

5 shows very low $\mathrm{SO}_{4}^{2-}$ concentrations below $2 \mathrm{~cm}$ in the sediment. Thus, the layer between 2 and $6.5 \mathrm{~cm}$ can be defined as a zone of active sulphide precipitation (zone IV) (Fig. 6b). Copper, Ni (Fig. 6), As and Mo (Fig. 5) show clear enrichments in the sulphide precipitation zone, whereas Sr and $\mathrm{Ba}$ (Fig. 2) decrease in this zone.

\subsubsection{Zone of manganese dissolution and iron precipitation (V)}

10 The concomitant increase of Fe/S and Fe/Ti from $12 \mathrm{~cm}$ with a peak at a depth of $10 \mathrm{~cm}$ (Fig. 6) are related to the mining activities discussed for zone III (see above). The rather low constant $\mathrm{Fe} / \mathrm{S}$ ratio around a minimum value of 2 between approximately 2.5 and $6.5 \mathrm{~cm}$ depth indicates the presence of Fe sulphides. The increase of $\mathrm{Fe} / \mathrm{Ti}$ from $6.5 \mathrm{~cm}$ depth towards a local peak in the $\mathrm{Fe} / \mathrm{Ti}$ ratio at $5 \mathrm{~cm}$ coincides with the particulate $\mathrm{S}$ peak, which supports the formation of authigenic Fe sulphides. Increasing $\mathrm{Fe} / \mathrm{S}$ (and $\mathrm{Fe} / \mathrm{Ti}$ ) ratios, and the low particulate $S$ concentration in the top $2 \mathrm{~cm}$ of the sediment column indicate the presence of a non-sulfidic phase, most likely Fe oxyhydroxides (Fe oxyhydroxide zone). Right below the sediment surface the particulate Mn concentration drops, indicating significant dissolution of Mn oxyhydroxides in the upper sediment. This is illustrated by the continuous decrease in the Mn concentration from the sediment water interface down to $5 \mathrm{~cm}$ (Fig. 6).

\subsection{Water column}

\subsubsection{Conductivity}

Conductivity varied between 102 and $126 \mu \mathrm{S} \mathrm{cm}^{-1}$ in the water column. The highest

values were measured in April and the lowest during August. In April the water column
BGD

8, 273-321, 2011

\section{Manganese redox cycling in Lake Imandra \\ J. Ingri et al.}

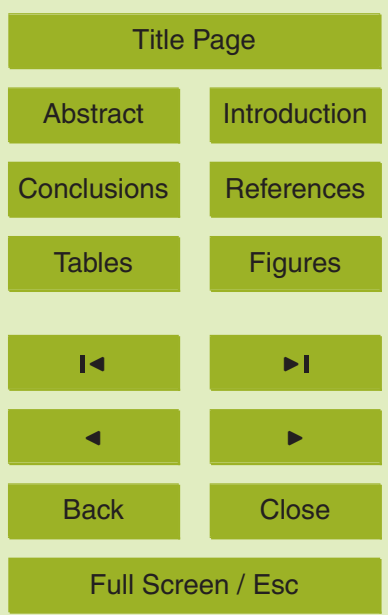

Printer-friendly Version

Interactive Discussion 
can be divided in three different water masses, based on the conductivity: increased conductivity in the surface water ( 1 to $8 \mathrm{~m}$ depth), a layer with slightly increasing conductivity down to $28 \mathrm{~m}$, and a $2 \mathrm{~m}$ thick bottom layer with enhanced conductivity. In August and October the conductivity was almost uniformly distributed (Fig. 7e).

\section{4.2.2 Temperature, dissolved oxygen, $\mathrm{pH}$, alkalinity and suspended matter}

The ice cover on Lake Imandra at the time of sampling in April was approximately $0.7 \mathrm{~m}$ thick. Just beneath the ice cover and in the upper $6 \mathrm{~m}$, the temperature was about $1^{\circ} \mathrm{C}$. From a depth of $7 \mathrm{~m}$ the temperature rose continuously towards the bottom to $3^{\circ} \mathrm{C}$, $0.1 \mathrm{~m}$ from the sediment surface. In August the temperature was around $12^{\circ} \mathrm{C}$ in the bottom water and rose to $15^{\circ} \mathrm{C}$ in the upper water column. After autumn turnover in October, the lake was isothermal $\left(3.9^{\circ} \mathrm{C}\right)$ and hence well mixed (Fig. 7$)$.

A uniform oxygen concentration was measured after overturn in October. In April the $\mathrm{O}_{2}$ concentration declined continuously downwards from a depth of $5 \mathrm{~m}$ and was $0.03 \mathrm{mM}$ (corresponding to $5 \%$ of $\mathrm{O}_{2}$ saturation) $10 \mathrm{~cm}$ from the bottom. In August the oxygen depletion was not as pronounced as in April, and a relative high dissolved oxygen content, around $0.4 \mathrm{mM}$, was measured even in the bottom water (Fig. 7).

The $\mathrm{pH}$ ranged from 6.5 to 7.3 throughout the seasons with the lowest $\mathrm{pH}$ values in April and the highest in October. In April, pH decreased towards the bottom, especially, in the deepest five metres. Enhanced $\mathrm{pH}$ values were measured between 3 and $7 \mathrm{~m}$ in 20 April (Fig. 7).

The distribution of alkalinity was uniform in October and August. During winter stratification in April, a significant increase was measured at $0.1 \mathrm{~m}$ above the sediment surface, and a smaller local maximum at $2 \mathrm{~m}$ above the bottom (Fig. 7).

The concentration of particles $(>0.45 \mu \mathrm{m})$ in the water column in April was al25 most constant around $0.3 \mathrm{mgl}^{-1}$ between 5 and $22 \mathrm{~m}$. Above $5 \mathrm{~m}$ the concentration was slightly enhanced and below $22 \mathrm{~m}$ suspended matter increased to approximately $1.5 \mathrm{mg} \mathrm{I}^{-1}$ near the sediment-water interface (Fig. 7). The suspended matter contained between 10 and $23 \%$ of dry weight $C$ (corresponding to a concentration of particulate
BGD

8, 273-321, 2011

\section{Manganese redox cycling in Lake Imandra \\ J. Ingri et al.}

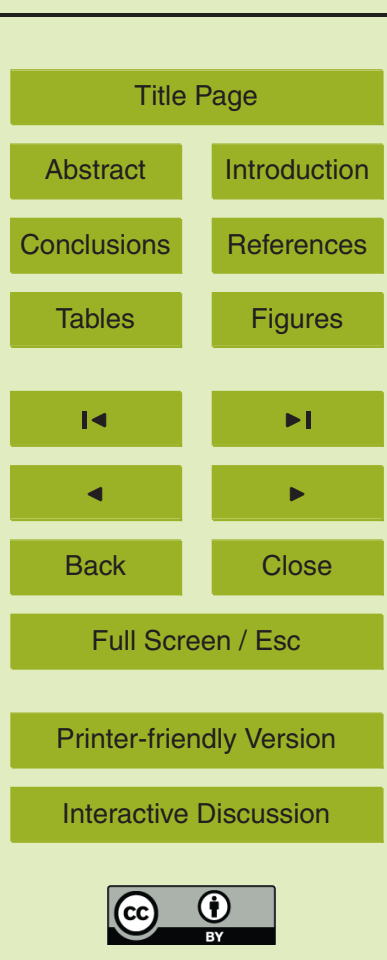


C between 9 and $20 \mu \mathrm{mol} / \mathrm{kg} \mathrm{DW}$ ), with the lowest values in the bottom water. The concentration of particulate $\mathrm{C}$ in April varied between 4.3 to $12.8 \mu \mathrm{M}$. The particulate $C$ profile showed a general increase towards the bottom with a pronounced local maximum at $5 \mathrm{~m}$ above the bottom (Fig. 7).

\section{4.2.3 Nitrogen and phosphorous}

The nitrate concentration in April showed enhanced concentrations above $7 \mathrm{~m}$ depth and a minimum at $8 \mathrm{~m}$. From $8 \mathrm{~m}$, the concentration increased continuously down to the bottom (Fig. 8). Ammonium was strongly enriched close to the sediment water interface in April, and reached fairly constant levels above $28 \mathrm{~m}$ (Fig. 8). Total nitrogen 10 was relatively high close to the ice and close to the bottom. Particulate nitrogen showed enhanced values close to the ice and below $22 \mathrm{~m}$ with a peak at $1 \mathrm{~m}$ depth above the sediment-water interface (Fig. 8). Phosphate showed enhanced concentrations in the upper $10 \mathrm{~m}$, and significant enrichment close to the sediment water interface (Fig. 8). Particulate $P$ showed relatively enhanced concentrations down to a depth of $10 \mathrm{~m}$, rather constant concentrations between $10 \mathrm{~m}$ and $20 \mathrm{~m}$ and increased concentrations towards the bottom in April.

\subsubsection{Dissolved and suspended major elements}

Dissolved $\mathrm{Ca}, \mathrm{Mg}, \mathrm{Si}, \mathrm{Mn}$ and nitrate show an increasing concentration towards the bottom in April, indicating a significant flux from the sediment (Figs. 8, 9 and 10). This flux influences the concentration throughout the water column. The sulphate profiles, however, do not show any changes between the seasons, except for the inflow of polluted surface water in April (Fig. 9). The reason for this is most likely that the sediment is no source of sulphate because of extensive sulphate reduction in the sediment, as indicated by the low pore water concentrations (Fig. 9). The $\mathrm{SO}_{4}^{2-}$ concentration in

25 April was around $240 \mu \mathrm{M}$, with only small variation, except for the upper $6 \mathrm{~m}$ with concentration close to $285 \mu \mathrm{M}$. Sulphate decreased rapidly in the pore water in the upper

\section{BGD}

$8,273-321,2011$

\section{Manganese redox cycling in Lake Imandra \\ J. Ingri et al.}

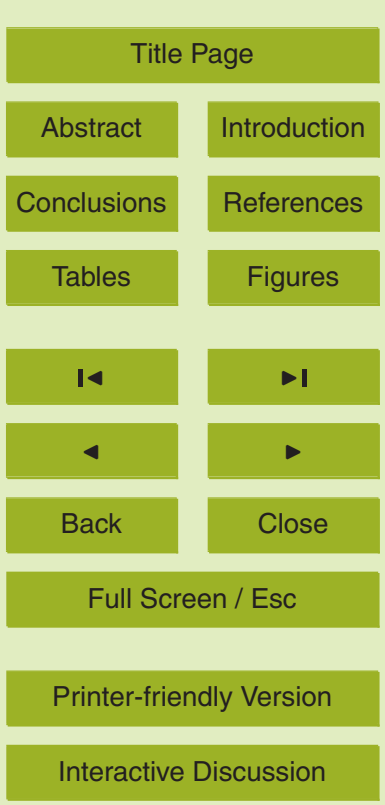

Interactive Discussion 
part of the sediment, and showed a low concentration $(20 \mu \mathrm{M})$ already at a depth of $5 \mathrm{~cm}$ in the sediment. Furthermore, Na shows no large contribution from the sediment. Sodium is enriched in the polluted surface water but shows a more or less uniform concentration down to the bottom in April (Fig. 9).

\section{4.2.5 Seasonal distributions of Fe and Mn}

The total concentration of Fe during the measured period ranged between 0.08 $1.64 \mu \mathrm{M}$ (average $0.3 \mu \mathrm{M}$ ) and was lowest in April and highest in August (Fig. 10) due to increase in particulate Fe concentration. The dissolved Fe concentration, approximately $50 \mathrm{nM}$, was rather uniform throughout the water column and during the seasons, except for small peaks at $0.1 \mathrm{~m}$ and $2 \mathrm{~m}$ from the sediment surface in April (Fig. 10). In April $64 \%$, in August $90 \%$ and in October $78 \%$ of the total Fe concentration was in a particulate phase. The concentration of dissolved $\mathrm{Fe}$ in the pore water in April reached $179 \mu \mathrm{M}$, which corresponds to a 830-fold increase, compared with the dissolved $\mathrm{Fe}$ concentration at $0.1 \mathrm{~m}$ above the sediment surface (Fig. 10). Also, the particulate Fe a depth of $2 \mathrm{~m}$ above the sediment surface.

The total Mn concentration $\left(\mathrm{Mn}_{\mathrm{T}}\right)$ ranged between 30 and $7363 \mathrm{nM}$ (average $921 \mathrm{nM}$ ) and was rather uniform in the upper $15 \mathrm{~m}$ of the water column with values of around $40 \mathrm{nM}$ in April, $200 \mathrm{nM}$ in August and around $100 \mathrm{nM}$ during the fall turnover in October 20 (Fig. 10). Particulate Mn accounted for $63 \%$ in April and for over $90 \%$ of the total Mn concentration in August and October. In the bottom waters, $\mathrm{Mn}_{\mathrm{T}}$ increased significantly (245-fold increase) towards the bottom in April and, to some smaller extent, in August due to increase in both dissolved and particulate Mn concentrations (Fig. 10). The concentration of the dissolved $\mathrm{Mn}$ in the porewater in April ranged between 51 and $75 \mu \mathrm{M}$

with the highest value in the upper $2 \mathrm{~cm}$ of the sediment column, a 29-fold increase compared with the dissolved $\mathrm{Mn}$ concentration of $2.6 \mu \mathrm{M}$ at $0.5 \mathrm{~m}$ above the sediment surface. There was a maximum (around $6500 \mathrm{nM}$ ) in the dissolved Mn concentrations at $2 \mathrm{~m}$ above the sediment surface, together with local minima in the particulate $\mathrm{Mn}$
BGD

8, 273-321, 2011

\section{Manganese redox cycling in Lake Imandra \\ J. Ingri et al.}

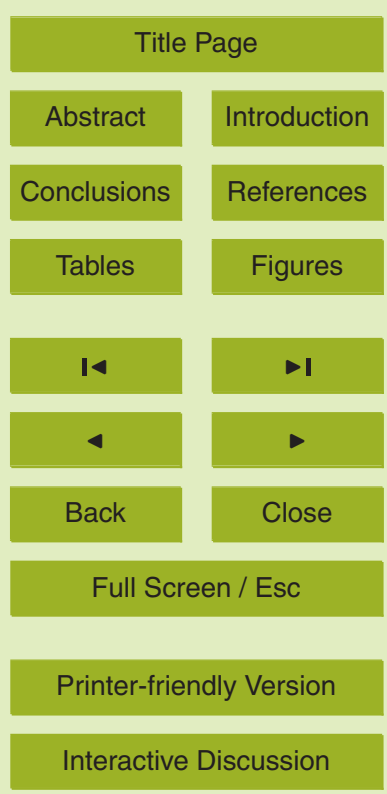

Interactive Discussion 
concentration. The particulate Mn profile in April showed two well-defined peaks at $1 \mathrm{~m}$ $(5660 \mathrm{nM})$ and $3 \mathrm{~m}(2070 \mathrm{nM})$ above the sediment surface (Fig. 10).

\subsubsection{Dissolved and particulate trace elements}

The dissolved Al concentration showed enhanced values close to the sediment-water the dissolved $\mathrm{Al}$ in the pore water reached $14 \mu \mathrm{M}$, corresponding to a 47-fold increase, compared with the dissolved Al concentration closest to the bottom (Table 2). The Al concentration reached the lowest value at a depth of $29 \mathrm{~m}$ and showed enhanced values between 25 and $15 \mathrm{~m}$ and above $5 \mathrm{~m}$. The particulate Al concentration was 10 relatively uniform in the upper $20 \mathrm{~m}$, but increased towards the sediment surface with a well-defined peak at $2 \mathrm{~m}$ above the bottom. The particulate Al form accounted for approximately $40-45 \%$ of the total Al concentration in the upper $25 \mathrm{~m}$ and up to $73 \%$ in the deepest $5 \mathrm{~m}$.

The average dissolved concentrations for $\mathrm{Cu}(51 \mathrm{nM}), \mathrm{Ni}(205 \mathrm{nM})$ and Mo (11 nM) 15 in Lake Imandra are significantly higher, while Co $(2.0 \mathrm{nM})$ and $\mathrm{Zn}(10.5 \mathrm{nM})$ are in the range of dissolved metal concentrations reported for open and permanently icecovered lake systems, e.g., Lake Vanda: $\mathrm{Ni}(3-113 \mathrm{nM}), \mathrm{Cu}(2.8-34.6 \mathrm{nM})$ and $\mathrm{Zn}$ (3.2-54.6 nM) (Green et al., 2004), Lake Joyce: Ni (8-26.8 nM), Cu (3.8-30.8 nM) and Co (0.3-13.65 nM) (Shacat et al., 2004), Hall Lake: Co (0.7-50 nM), Cu (0.6-17 nM), 20 Mo (0.7-2.6 nM), Ni (13-32 nM) and Zn (4.3-370 nM) (Balistrieri et al., 1994), Great Lakes: Cu (11-16.8 nM), Zn (1.3-4.3 nM) (Nriagu, 1996), Lake Sammanish: Co (0.01$5.9 \mathrm{nM})$, Ni 3.6-8.3 nM, Cu (1.8-8.3 nM) (Balistrieri et al., 1992).

Dissolved $\mathrm{Co}, \mathrm{Cu}, \mathrm{Mo}, \mathrm{Ni}, \mathrm{Pb}$ and $\mathrm{Zn}$ and particulate $\mathrm{Co}, \mathrm{Cu}, \mathrm{Pb}$ and $\mathrm{Zn}$ were elevated in the upper $8 \mathrm{~m}$ in April, while the dissolved Ba concentration was depleted 25 compared with water between depths of 10 and $20 \mathrm{~m}$ (Fig. 12). Throughout the layer between $10 \mathrm{~m}$ and $20 \mathrm{~m}$ the dissolved $\mathrm{Cu}$ and Mo concentrations decreased with depth, while dissolved $\mathrm{Ba}, \mathrm{Co}, \mathrm{Ni}$ and $\mathrm{Zn}$ concentrations were rather uniform (Fig. 12). In the bottom water, the concentrations of dissolved $\mathrm{Ba}$, Mo and $\mathrm{Zn}$ showed pronounced 288

\section{BGD}

$8,273-321,2011$

\section{Manganese redox cycling in Lake Imandra \\ J. Ingri et al.}

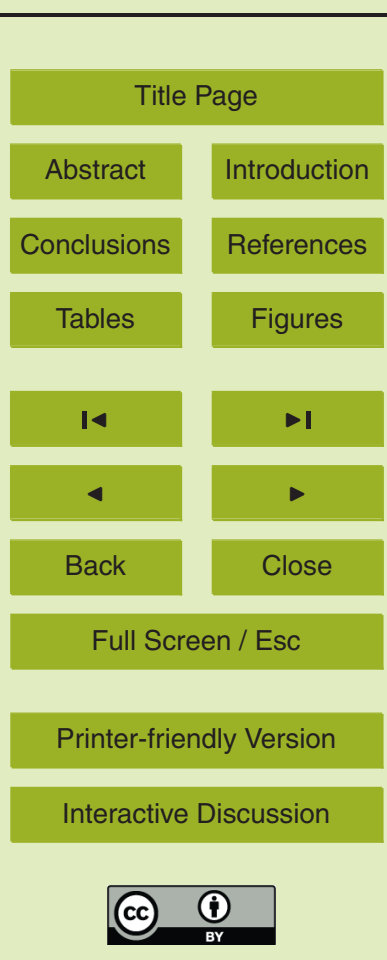


peaks at $2 \mathrm{~m}(\mathrm{Ba}$ and $\mathrm{Mo})$ and $3 \mathrm{~m}(\mathrm{Zn})$ above the bottom. The concentration of the dissolved $\mathrm{Zn}$ in the porewater was $350 \mathrm{nM}$, which corresponds to a 110-fold increase, compared with the dissolved $\mathrm{Zn}$ concentration at $0.1 \mathrm{~m}$ above the sediment surface (Table 2). Dissolved Cu concentration in porewater $(\approx 60 \mathrm{nM})$ was slightly higher com5 pared to dissolved Cu concentration measured in the deepest $2 \mathrm{~m}(40-50 \mathrm{nM}$ ) (Table 2 ). Dissolved $\mathrm{Ni}$ concentration increased significantly in the deepest $5 \mathrm{~m}$, culminating in a maximum at $0.1 \mathrm{~m}$, where concentration reached $580 \mathrm{nM}$. Below the sediment-water interface the dissolved Ni concentration was approximately $300 \mathrm{nM}$ (Fig. 10, Table 2). The particulate concentrations of $\mathrm{Ba}, \mathrm{Co}, \mathrm{Cu}, \mathrm{Mo}$ and Ni were rather uniform throughout 10 the upper 22-25 $\mathrm{m}$ (with the exception of elevated particulate $\mathrm{Cu}$ and Co concentrations in the upper $8 \mathrm{~m}$ ). However, in the bottom water (deepest $5 \mathrm{~m}$ ) particulate $\mathrm{Ba}, \mathrm{Co}$, $\mathrm{Cu}, \mathrm{Mo}, \mathrm{Ni}$ and $\mathrm{Zn}$ all showed the largest increase in concentrations. In the deepest five metres the particulate form accounted for up to Mo (65\%), Ba (60\%), Co (50\%), $\mathrm{Zn}(40 \%)$, Ni (25\%) and $\mathrm{Cu}(15 \%)$ of the total metal concentration, while in the upper $1525 \mathrm{~m}$ all investigated metals were present mainly in dissolved form, which accounted for more than $90 \%$ of the total concentration for $\mathrm{Ba}, \mathrm{Co}, \mathrm{Cu}, \mathrm{Mo}, \mathrm{Ni}$ and $\mathrm{Zn}$ (Tables 2 and 3). For $\mathrm{Pb}$, the particulate form, on the average, accounted for $51 \%$ of the total concentration, but in contrast to the other trace elements, $\mathrm{Pb}$ was mainly present in particulate form (up to $84 \%$ ) in the upper $15 \mathrm{~m}$ of the water column.

20 Total concentration of $\mathrm{Ni}$ in the water column during the different sampling periods ranged between 108 and $450 \mathrm{nM}$ (average $196 \mathrm{nM}$ ). The particulate Ni concentration accounted for $6 \%$ in April, $17 \%$ in August and 14\% in October. In the upper $20 \mathrm{~m}$ of the water column the dissolved $\mathrm{Ni}$ concentration was almost constant during the different seasons, but increased significantly towards the bottom in April and, to a lesser extent, in August (Fig. 10). The maximum dissolved Ni concentration of $580 \mathrm{nM}$ was measured $0.1 \mathrm{~m}$ above the sediment in April. In contrast to dissolved Fe and Mn the porewater concentration for $\mathrm{Ni}(\approx 280 \mathrm{nM})$ decreased with depth in the sediment and was lower than the dissolved Ni concentration immediately above the sediment surface (Fig. 10). The particulate Ni concentration was almost constant throughout the upper $25 \mathrm{~m}$ of the

\section{BGD}

$8,273-321,2011$

\section{Manganese redox cycling in Lake Imandra \\ J. Ingri et al.}

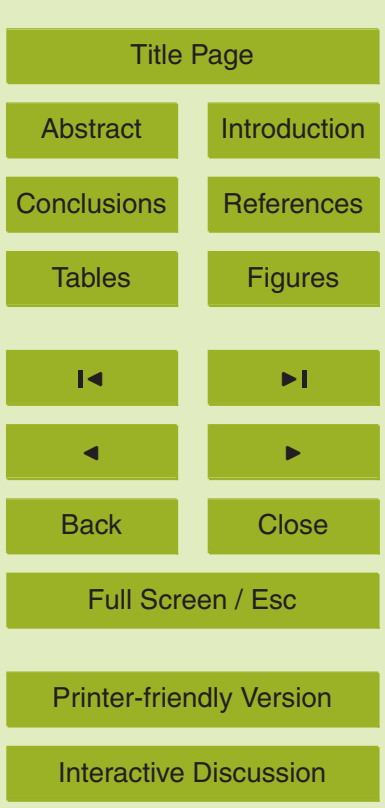


water column, and was highest in August and lowest in April. Similar to particulate Mn profile, particulate Ni showed two well-defined peaks in the deepest five metres (Fig. 10).

\section{Discussion}

5 The conductivity curve in April (Fig. 7e) summarises the two major processes influencing the distribution of elements in Lake Imandra. The high-conductivity water layer close to the surface in April most likely reflects the inflow of direct industrial discharges, from the $\mathrm{Cu}-\mathrm{Ni}$ smelter and the apatite concentration plant from the northern (most polluted) part of the lake (Fig. 1), and to some extent, pollutants transported by melt 10 water. Snow had started melting in the area at the time of sampling. As a result of the stratification, the inflowing water had not mixed much with the underlying lake water at the time of sampling. Dissolved concentrations of sulphate, $\mathrm{Na}, \mathrm{Mg}$, nitrate, phosphate, $\mathrm{Co}, \mathrm{Cu}, \mathrm{Ni}, \mathrm{Mo}, \mathrm{Pb}$ and $\mathrm{Zn}$ are enhanced in this water. Furthermore, enhanced particulate concentrations of $\mathrm{Ca}, \mathrm{K}, \mathrm{Mg}, \mathrm{Na}, \mathrm{S}, \mathrm{P}, \mathrm{N}, \mathrm{Co}, \mathrm{Cu}, \mathrm{Pb}$ and $\mathrm{Zn}$ are clearly 15 seen in the inflowing water.

The distinct increase in conductivity close to the bottom during winter stratification indicates a flux of dissolved ions from the sediment column to the water. This has a significant impact on the concentrations of several elements in Lake Imandra during winter, and it is important to understand the processes explaining this large flux of both 20 major and trace elements from the sediment. Most of the discussion below is therefore focused on the data from the winter stratification period in April.

\subsection{Coupling between the nitrogen and the manganese redox cycles}

Attention has been paid to new alternative routes during $\mathrm{N}$ mineralization, particularly in marine sediments, where Mn oxides play a key role in anaerobic ammonium oxidation to nitrite, nitrate and $\mathrm{N}_{2}$ (Hulth et al., 2005). Coupling between the $\mathrm{N}$ and $\mathrm{Mn}$

\section{BGD}

8, 273-321, 2011

\section{Manganese redox cycling in Lake Imandra \\ J. Ingri et al.}

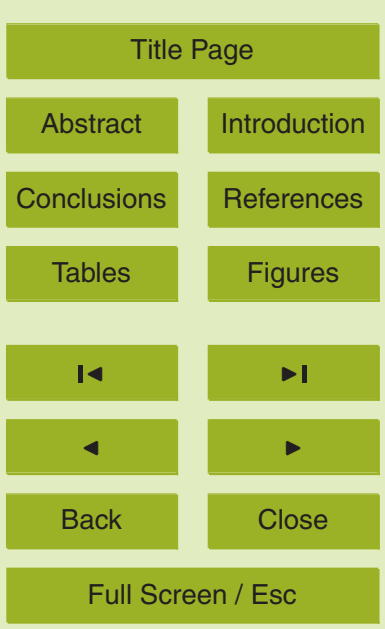

Printer-friendly Version

Interactive Discussion 
redox cycles has been observed at the oxic/anoxic interfaces in the Black Sea (Tebo, 1991; Murray et al., 1995; Oguz et al., 2001; Konovalov et al., 2004) and sediments of the Panama Basin (Balistrieri and Murray, 1986; Aller et al., 1998) and the equatorial Atlantic, Cabot Strait, Scotia slope (Luther et al., 1997). In particular, mounting cir5 cumstantial evidence suggests that within organic and Mn-rich regions of marine sediments, the $\mathrm{N}$ and Mn cycles may be closely coupled through the overall Reactions (R1) and (R2) suggested by Hulth et al. (1999):

$\mathrm{NH}_{4}^{+}+4 \mathrm{MnO}_{2}+6 \mathrm{H}^{+} \rightarrow 4 \mathrm{Mn}^{2+}+\mathrm{NO}_{3}^{-}+5 \mathrm{H}_{2} \mathrm{O}$

$2 \mathrm{NO}_{3}^{-}+5 \mathrm{Mn}^{2+}+4 \mathrm{H}_{2} \mathrm{O} \rightarrow 5 \mathrm{MnO}_{2}+\mathrm{N}_{2}+8 \mathrm{H}^{+}$

10 Manganese shows highly dynamic seasonal distribution patterns in Lake Imandra (Fig. 10). Shortly after autumn overturn in the lake (October), dissolved Mn showed an almost constant concentration $(10 \mathrm{nM})$ throughout the water column. In August the concentration above $20 \mathrm{~m}$ was almost identical to that of October, but below that depth the concentration increased linearly towards the bottom. In April, at the end of the ice-covered period, a complicated pattern with local maxima and minima had developed (Fig. 10). The dissolved Mn concentration in April showed a drastic overall increase from a depth of $15 \mathrm{~m}$ down to the bottom, indicating a significant flux of $\mathrm{Mn}$ from the sediment. The low concentration of particulate $\mathrm{Mn}$ in the sediment (below $100 \mathrm{mmol} \mathrm{kg}^{-1}$ ) compared with $8000 \mathrm{mmol} \mathrm{kg}^{-1}$ in the bottom water indicates a significant reduction and dissolution of particulate $\mathrm{Mn}$ close to the sediment-water interface (Fig. 10). High dissolved Mn concentrations, $80000 \mathrm{nM}$, were measured at $2 \mathrm{~cm}$ into the sediment (Fig. 10). Hence, a concentration gradient is formed, and dissolved Mn in the sediment is diffusing up into the bottom water. When the reduced dissolved $\mathrm{Mn}$ reaches measurable concentrations of oxygen, $\mathrm{Mn}$ is oxidized, precipitates and forms Mn oxide (-hydroxide) particles. This is the theoretical scenario for Mn cycling in oxidized bottom water, based on the thermodynamic properties for different precipitated Mn oxide and dissolved Mn (Davison, 1993).
BGD

$8,273-321,2011$

\section{Manganese redox cycling in Lake Imandra \\ J. Ingri et al.}

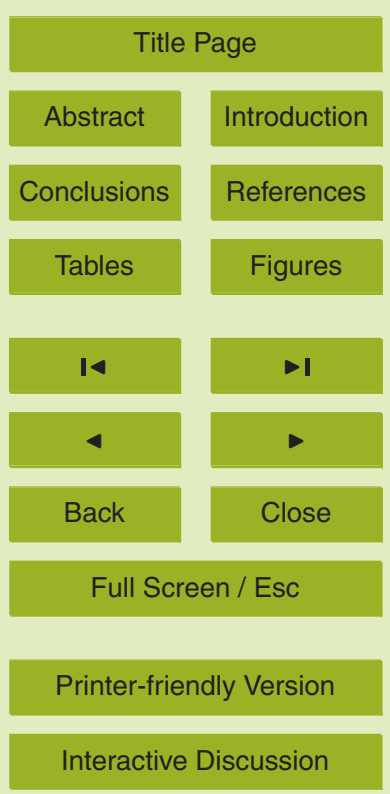


The dissolved Fe concentration changes dramatically (by three orders of magnitude) close to the sediment-water interface, indicating that the redox boundary for $\mathrm{Fe}$ (II) to $\mathrm{Fe}(\mathrm{III})$ is situated within the upper $2 \mathrm{~cm}$ of the sediment (Fig. 10). In contrast to Fe, precipitation of dissolved $\mathrm{Mn}$ takes place above the sediment-water interface. However, 5 data clearly show that dissolved $\mathrm{Mn}$ is present at relatively high concentrations up to $10 \mathrm{~m}$ above the bottom in August, although the dissolved oxygen concentration is high. Furthermore, a striking feature in Fig. 10 is the double peaks of suspended $\mathrm{Mn}$ and corresponding changes in dissolved $\mathrm{Mn}$ in the bottom water in April. These two particulate peaks are separated by water with strongly enriched dissolved Mn concentration 10 (around $6000 \mathrm{nM}$ ) at $2 \mathrm{~m}$ above the sediment. The dissolved Mn peak is intriguing, because the bottom water has measurable concentrations of dissolved oxygen down to the sediment-water interface also in April (Fig. 7).

Green et al. (2004) have discussed a similar situation in oxic bottom water in Lake Wanda. They suggested that the presence of significant levels of reduced Mn(II) in 15 waters that are appreciably rich in dissolved oxygen could be attributed to lowered $\mathrm{pH}$ and low dissolved oxygen. They suggested that equilibrium of the type given in Reaction (R3) could explain locally increased dissolved Mn concentrations in oxic bottom water.

$$
\mathrm{Mn}_{3} \mathrm{O}_{4}(\mathrm{~s})+6 \mathrm{H}^{+}(\mathrm{aq}) \rightleftarrows \mathrm{Mn}^{2+}(\mathrm{aq})+1 / 2 \mathrm{O}_{2}(\mathrm{aq})+3 \mathrm{H}_{2} \mathrm{O}(\mathrm{aq})
$$

20 It is clear from this reaction that the solubility of the Mn oxide is strongly $\mathrm{pH}$-dependent. Even small variations in $\mathrm{pH}$ will have a strong impact on the dissolved $\mathrm{Mn}$ concentration. However, in Lake Imandra no variation was measured for $\mathrm{pH}$ between $2 \mathrm{~m}$ and $1 \mathrm{~m}$ above the bottom in April, and only a small decrease in dissolved oxygen was measured (Fig. 7). The dissolved Mn concentration, on the other hand, showed a drastic change from $6000 \mathrm{nM}(2 \mathrm{~m}$ above bottom) to $300 \mathrm{nM} 1 \mathrm{~m}$ above bottom (Fig. 10). We therefore suggest that the two particulate Mn peaks in Lake Imandra bottom water are the result of strong interactions between the $\mathrm{Mn}$ and $\mathrm{N}$ redox cycles.

The regulation of nitrification and denitrification, and their coupling, is complex due to the involvement of both aerobic and anaerobic processes, which are catalysed by 292
BGD

8, 273-321, 2011

\section{Manganese redox cycling in Lake Imandra}

J. Ingri et al.

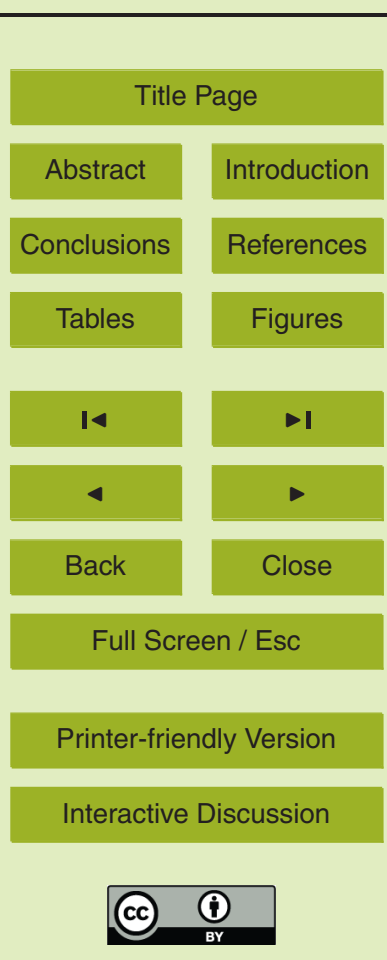


a wide suite of bacteria. Although denitrification is a relatively well-studied process, the bacterially mediated aerobic nitrification and anaerobic denitrification processes do not exclude alternative pathways. Coupled nitrogen and metal redox reactions constitute important examples of new routes during $\mathrm{N}$ mineralization (Hulth et al., 2005). The oxi5 dation of organic $\mathrm{N}$ and $\mathrm{NH}_{4}^{+}$by $\mathrm{MnO}_{2}$ to either $\mathrm{NO}_{2}^{-} / \mathrm{NO}_{3}^{-}$(Hulth et al., 1999; Anschutz et al., 2000) or directly to $\mathrm{N}_{2}$ (Luther et al., 1997) is thermodynamically favourable at conditions similar to those found in marine pore waters (Luther et al., 1997; Hulth et al., 1999), and based on thermodynamic considerations, $N_{2}$ has been assumed be the end-product when $\mathrm{Mn}$ oxide is the terminal electron acceptor in the anaerobic oxidation 10 of organic matter (e.g., Froelich et al., 1979; Reimers et al., 1992).

Anaerobic nitrification coupled to $\mathrm{Mn}$ reduction has been suggested to explain low ammonium concentrations relative to soluble manganese in the $\mathrm{Mn}$ oxide-rich sediments of the Panama Basin (Aller et al., 1998), in the sediment of the equatorial Atlantic, Cabot Strait, Scotia slope (Luther et al., 1997) and at the oxic-anoxic interface of Black Sea (Murray et al., 1995). Indications of such a process were also found in laboratory experiments with surface marine sediment from Long Island Sound (USA) (Hulth et al., 1999). In addition to anaerobic ammonium oxidation by Mn oxides, solute distribution patterns suggested anaerobic $\mathrm{Mn}$ (II) oxidation coupled to nitrate reduction (Tebo, 1991; Murray et al., 1995; Luther et al., 1997; Aller et al., 1998; Hulth et al., 1999; Konovalov et al., 2004). Hulth and co-workers observed transient accumulations of nitrate in anoxic jar incubations of sediment, including some with added Mn oxide. Nitrate was produced simultaneously with $\mathrm{Mn}$ (II) during Mn-oxide reduction, and the rate of anoxic nitrification was directly proportional to the quantity $\mathrm{Mn}$ oxide available. Nitrate was rapidly consumed again, and it was suggested that a continuous nitrification coupled to Mn-oxide reduction was hidden by concomitant denitrification.

Considering the data on the coupling between the Mn-redox cycle and nitrogen suggested in recent literature, we make the following interpretation of the complex Imandra $\mathrm{Mn}$ profile in April (Fig. 10). At $2 \mathrm{~m}$ above the bottom there is a zone of active $\mathrm{Mn}$ reduction, denitrification, mineralization of organic material and Fe cycling, which can be

\section{BGD}

$8,273-321,2011$

\section{Manganese redox cycling in Lake Imandra}

J. Ingri et al.

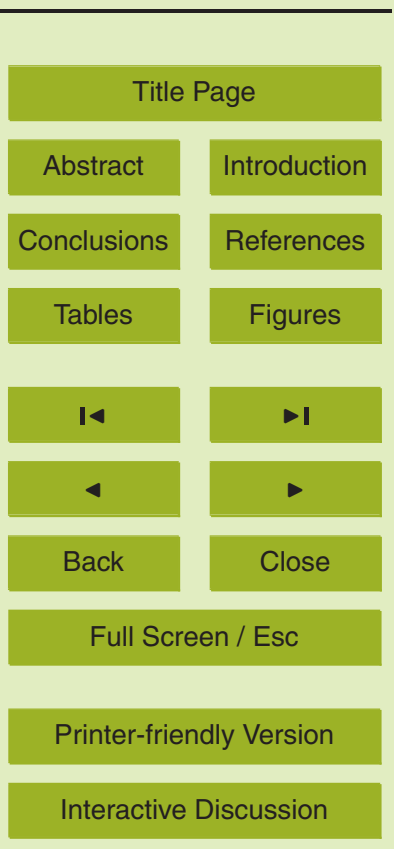


illustrated by the overall reactions:

$6 \mathrm{CH}_{2} \mathrm{O}+4 \mathrm{NO}_{3}^{-}+\mathrm{MnO}_{2}+2 \mathrm{Fe}(\mathrm{OH})_{3}+4 \mathrm{H}^{+} \rightleftarrows 2 \mathrm{~N}_{2}+\mathrm{Mn}^{2+}+2 \mathrm{Fe}^{2+}+6 \mathrm{HCO}_{3}^{-}+8 \mathrm{H}_{2} \mathrm{O}(\mathrm{R} 4)$

BGD

$10 \mathrm{Fe}^{2+}+2 \mathrm{NO}_{3}^{-}+24 \mathrm{H}_{2} \mathrm{O} \rightleftarrows 10 \mathrm{Fe}(\mathrm{OH})_{3}+\mathrm{N}_{2}+18 \mathrm{H}^{+}$

$2 \mathrm{Fe}^{2+}+\mathrm{MnO}_{2}+4 \mathrm{H}_{2} \mathrm{O} \rightleftarrows 2 \mathrm{Fe}(\mathrm{OH})_{3}+\mathrm{Mn}^{2+}+2 \mathrm{H}^{+}$

5 This zone is characterized by high dissolved Mn (Fig. 10), a local minimum in nitrate and increased ammonium (Fig. 8), increased total nitrogen (Fig. 8) and slightly increased alkalinity (Fig. 7). To explain the concomitant increase of dissolved and particulate Fe in this zone (Fig. 10) a combination of Reactions (R4), (R5) and (R6) is plausible. Nitrate reduction coupled to $\mathrm{Fe}(\mathrm{II})$ oxidation has been reported for a variety of denitrifying bacteria (e.g., Benz et al., 1998; Hafenbradl et al., 1996). Oxidation of $\mathrm{Fe}(\mathrm{II})$ by $\mathrm{Mn}(\mathrm{IV})$ has been studied by Postma $(1985,2000)$. It is likely that we have all the three major electron acceptors, nitrate, Mn- and Fe-oxide-hydroxides, operating in this zone between dominance of oxygen oxidation (above) and sulphate reduction (below) in the sediment. Manganese is diffusing upwards and downwards from this zone.

15 Oxygen is most likely the major oxidant for $\mathrm{Mn}$ (II) above this zone. However, below the oxygen layer, the dominant oxidant is probably not oxygen but nitrate. Hence, the $2 \mathrm{~m}$ thick anoxic water column above the sediment probably continue approximately 2 $\mathrm{cm}$ down into the sediment. The rest of the sediment can be classified as sulfidic, as indicated by the low dissolved sulphate concentration.

Decrease in the ammonium and nitrate concentration between 0.5 and $2 \mathrm{~m}$ above the bottom can be the result of $\mathrm{Mn}$ (II) oxidation coupled to nitrate reduction and ammonium oxidation according to the overall reaction:

$\mathrm{Mn}^{2+}+\mathrm{NO}_{3}^{-}+\mathrm{NH}_{4}^{+} \rightleftarrows \mathrm{MnO}_{2}+\mathrm{N}_{2}+2 \mathrm{H}^{+}+\mathrm{H}_{2} \mathrm{O}$

This zone is characterized by local maximum in particulate Mn (Fig. 10), lowered nitrate and ammonium (Fig. 8) and lowered pH (Fig. 7). In Reaction (R7) we can recognize

\section{Manganese redox cycling in Lake Imandra}

J. Ingri et al.

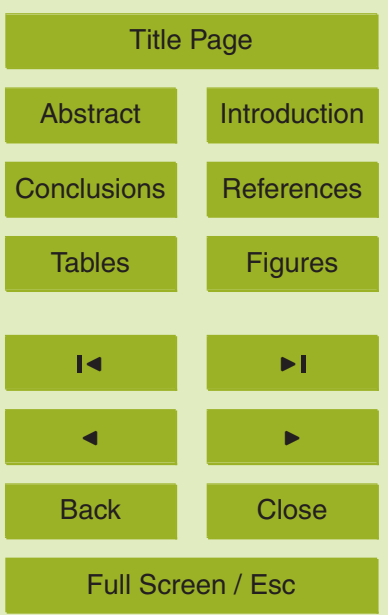

Printer-friendly Version

Interactive Discussion 
two reactions: oxidation of $\mathrm{Mn}$ by nitrate, and the anammox reaction, anaerobic ammonium oxidation. Anammox has been found in a range of environments including marine sediments, sea ice and anoxic water columns (Dalsgaard et al., 2005). For anammox bacteria isolated from wastewater treatment facilities, the anammox process 5 appears to occur only under strictly anaerobic conditions. However, oxygen concentrations likely fluctuate in the nitrate-containing zones in natural environments and as a result, natural /anammox bacteria/ may have developed a higher tolerance towards oxygen (Dalsgaard et al., 2005). It is likely that anammox is dominating close to the sediment water interface and Mn oxidation by nitrate higher up in this zone.

10 Close to the sediment water-interface and partly within the upper section of the sediment a zone of active nitrification probably occurs, thus creating the source for nitrate (Fig. 8). Anoxic nitrification can be illustrated by the reaction:

$4 \mathrm{MnO}_{2}+\mathrm{NH}_{4}^{+}+6 \mathrm{H}^{+} \rightleftarrows 4 \mathrm{Mn}^{2+}+\mathrm{NO}_{3}^{-}+5 \mathrm{H}_{2} \mathrm{O}$

The oxidation of ammonium by Fe oxyhydroxides is less likely (see discussion in Hulth 15 et al., 1999; Anschuts et al., 2000). Luther and co-workers suggested that $\mathrm{MnO}_{2}$ consumed during the oxidation of organic- $\mathrm{N}$ and $\mathrm{NH}_{4}^{+}$in surface marine sediments and in the presence of $\mathrm{O}_{2}$ is readily regenerated by the oxidation of $\mathrm{Mn}(\mathrm{II})$ by $\mathrm{O}_{2}$ in a catalytic cycle that affects nitrogen speciation (Luther et al., 1997). In this catalytic cycle, the direct oxidation of organic matter by $\mathrm{MnO}_{2}$ is more thermodynamically favourable compared with $\mathrm{O}_{2}$ as a direct oxidant of organic matter, while $\mathrm{O}_{2}$ is the ultimate oxidant, since it is continually supplied from the overlying waters to re-oxidize the $\mathrm{Mn}$ (II) formed. However, both $\mathrm{MnO}_{2}$ and $\mathrm{O}_{2}$ oxidation of organic matter can occur simultaneously (Luther et al., 1997). Reduction of $\mathrm{MnO}_{2}$ in the presence of $\mathrm{O}_{2}$ has been observed in studies of Black Sea water (Tebo, 1991), in the water column of Lake Vanda,
Antarctica (Green et al., 2004) and Lake Joyce, Antarctica (Shacat et al., 2004).

\section{BGD}

$8,273-321,2011$

\section{Manganese redox cycling in Lake Imandra}

J. Ingri et al.

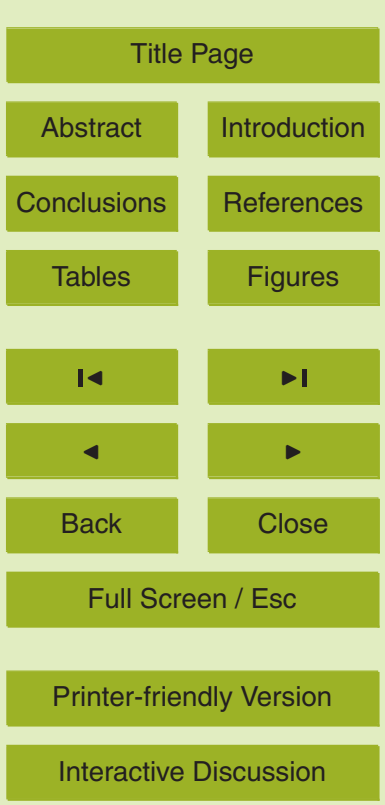




\subsection{Mn-controlled cycling of major and trace elements}

The major element data suggest that the elements $\mathrm{Ca}$ and $\mathrm{Mg}$ must be transported down to the sediment in particles that, to some extent, are dissolved and $\mathrm{Ca}$ and $\mathrm{Mg}$ are mobilized into the dissolved phase. It is therefore important to understand which type

5 of particles that are deposited and subsequently dissolved in the sediment. Particulate matter in lakes is a mixture of detrital particles (primary rock-forming minerals), organic matter and secondary (non-detrital) phases such as Fe-Mn oxyhydroxides, diatoms, etc. In Lake Imandra there are also particles from mining activities. This particulate fraction is a mixture of detrital particles, primary particles from the ore and secondary 10 particles. These different groups of particles can have an allogenic (transported into the lake from the catchment) origin and/or an authigenic origin (formed within the lake). Normalization of data can be used to estimate the amount of non-detrital particles, hence enabling interpretation of biogeochemical processes within the lake.

Aluminium and $\mathrm{Ti}$ are usually good indicators of detrital particles. Aluminium and 15 Ti show a strong linear correlation $(R=0.93)$ in particulate matter in this study, with an $\mathrm{Al} / \mathrm{Ti}$ ratio close to 26 in the upper $15 \mathrm{~m}$ in April. This is a close to the "average continental crust" (ACC) ratio (28) (Taylor and McLennan, 1985), which suggests that a large fraction of both elements is present in detrital particles in recent sediment material. However, in the bottom water (deepest $5 \mathrm{~m}$ ) the $\mathrm{Al} / \mathrm{Ti}$ ratio increases to 40 , indicating the presence of an Al phase with little Ti. Furthermore, the dissolved Al curve in April (Fig. 12, Table 2) suggests diffusion of dissolved Al from the sediment to the bottom water, and a subsequent enrichment of $\mathrm{Al}$ ( $\mathrm{Al} / \mathrm{Ti}$ ratio up to 40 ) in the particulate phase in the bottom water. Therefore, Ti has been used as an indicator of detrital particles and normalizing element in this study.

25 The element/Ti molar ratios for suspended Fe and Mn were rather constant throughout the upper $20 \mathrm{~m}$ of the water column (Fig. 13), with average values of 12 and 5.3, respectively, which can be compared with the ACC values of $11(\mathrm{Fe})$ and $0.2(\mathrm{Mn})$ (Taylor and McLennan, 1985). Hence, Fe is hosted mainly in detrital particles in the upper
BGD

$8,273-321,2011$

\section{Manganese redox cycling in Lake Imandra \\ J. Ingri et al.}

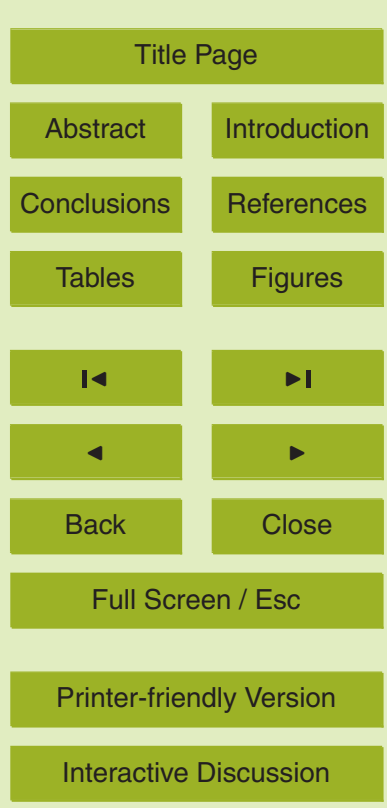


water column, while particulate $\mathrm{Mn}$ is mainly of non-detrital origin. Below $25 \mathrm{~m}$ depth the $\mathrm{Fe} / \mathrm{Ti}$ and $\mathrm{Mn} / \mathrm{Ti}$ curves show distinctly different patterns (Fig. 13). The Fe/Ti ratio increased in the bottom waters with maximum values of about 50 in the deepest $2 \mathrm{~m}$, thus indicating the presence of non-detrital $\mathrm{Fe}$. The $\mathrm{Mn} / \mathrm{Ti}$ ratio increased dramatically 5 and reached values up to 630 with a maximum at $1 \mathrm{~m}$ from the bottom and one submaximum at $3 \mathrm{~m}$ above the sediment surface. In the sediment column the $\mathrm{Mn} / \mathrm{Ti}$ ratio declined significantly to 2 at $0.5 \mathrm{~cm}$ and continued to decrease with depth approaching the $\mathrm{Mn} / \mathrm{Ti}$ ratio for ACC (Fig. 13).

The $\mathrm{Ca} / \mathrm{Ti}$ ratio in the suspended matter was almost constant down to a depth of $25 \mathrm{~m}$ 10 (Fig. 13). In the zone below $25 \mathrm{~m}$, down to the sediment, the $\mathrm{Ca} / \mathrm{Ti}$ ratio closely resembled the $\mathrm{Mn} / \mathrm{Ti}$ distribution, suggesting that $\mathrm{Ca}$ is transported to the sediment in $\mathrm{Mn}$-rich particles. Similarly, $\mathrm{Al} / \mathrm{Ti}, \mathrm{K} / \mathrm{Ti}, \mathrm{Mg} / \mathrm{Ti}, \mathrm{P} / \mathrm{Ti}$ together with $\mathrm{Ba} / \mathrm{Ti}, \mathrm{Cu} / \mathrm{Ti}, \mathrm{Co} / \mathrm{Mn}, \mathrm{Mo} / \mathrm{Ti}$, $\mathrm{Ni} / \mathrm{Ti}$ and $\mathrm{Zn} / \mathrm{Ti}$ all showed a distribution resembling the $\mathrm{Mn} / \mathrm{Ti}$ distribution in the bottom water (Fig. 13). It is therefore likely that Mn-rich particles act as a scavenger for all these elements. There are individual variations for the elements, and these variations will be discussed below. However, the main conclusion is that $\mathrm{Mn}$ is a major scavenger and carrier for the non-detrital fraction of these elements in the bottom water. None of the analyzed elements show a pattern that looks like the Fe/Ti ratio. Considering that most of the particulate $\mathrm{Fe}$ is in a detrital fraction during sedimentation through the water column, the lack of correlation between Fe and other elements is not surprising.

The average $\mathrm{S} / \mathrm{Ti}(\approx 15)$ value throughout the water column in Lake Imandra is much higher than the value in ACC (0.07) (Taylor and McLennan, 1985), indicating the influence of S-enriched particles from the industrial activities. The particulate $S$ and $\mathrm{S} / \mathrm{Ti}$ ratios are higher in suspended matter in the upper $10 \mathrm{~m}$, and show a decrease towards the sediment-water interface (Fig. 13). The S/Ti ratios in the upper $20 \mathrm{~m}$ show a pattern clearly different from $\mathrm{Al} / \mathrm{Ti}, \mathrm{Fe} / \mathrm{Ti}$ and $\mathrm{Mn} / \mathrm{Ti}$ (Fig. 13). Copper, $\mathrm{Pb}$ and $\mathrm{Zn}$ show similar Ti-normalized patterns compared with $\mathrm{S} / \mathrm{Ti}$ in the upper $20 \mathrm{~m}$, suggesting that these elements are transported to Lake Imandra in S-rich particles originating from industrial activities. However, the distribution patterns for $\mathrm{Cu}$ and $\mathrm{Zn}$ in the bottom water are
BGD

$8,273-321,2011$

\section{Manganese redox cycling in Lake Imandra \\ J. Ingri et al.}

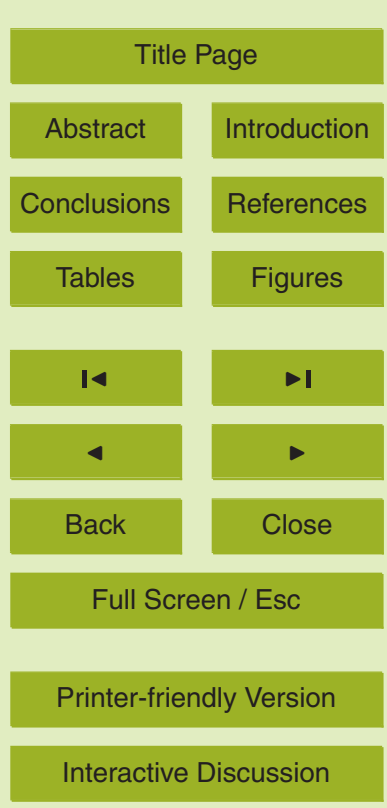


dominated by Mn cycling. The Pb distribution, on the other hand, appears to be totally dominated by the input of S-rich particles (Fig. 13). Barium, Co, Mo and Ni do not exhibit the same correlation to the S-rich particles in the upper water column (Fig. 13).

\subsubsection{Ni, Cu and Zn cycling}

5 The depth profiles for dissolved Ni showed dramatically seasonal changes, illustrating the role of $\mathrm{Mn}$ and its effects on Ni cycling. Throughout the water column, a more or less linear correlation between particulate $\mathrm{Ni}$ and $\mathrm{Mn}\left(R^{2}\right.$ adjusted $\left.=0.76\right)$ was observed. $\mathrm{Ni}$, similar to $\mathrm{Mn}$, showed significant accumulation of both the dissolved and particulate $\mathrm{Ni}$ in the hypolimnion in April, and, to lesser degree, in August (the hypolimhigher compared with the concentration in August) (Fig. 10). After lake overturn in October an almost constant dissolved Ni concentration was measured in the water column. The hypolimnetic Ni accumulation in the dissolved phase is the result of $\mathrm{Mn}$ oxide dissolution at, or close to, the sediment-water interface, liberating scavenged $\mathrm{Ni}$, thus creating a flux of dissolved $\mathrm{Ni}$ from the sediment.

The concentration profile for dissolved $\mathrm{Ni}$ in April indicates a point source for dissolved $\mathrm{Ni}$ in the surface sediment. From this point $\mathrm{Ni}$ is transported upwards in the water column, as well as down in the sediment. The highest concentrations of particulate $\mathrm{Ni}$ in April were found at $3 \mathrm{~m}$ above the sediment surface, correlated to the second $0.5 \mathrm{~m}$ (above bottom), in spite of the fact that the dissolved Ni concentration is higher and the total amount of particulate $\mathrm{Mn}$ is higher at these depths (compared with $3 \mathrm{~m}$ above bottom) (Fig. 10). A possible explanation for this is that the competition for adsorption sites on the Mn-rich phase is higher at the deeper level. A high affinity of (1964) and Posselt et al. (1968). They suggested that the uptake of Mn(II) was part of an ion exchange reaction with a concomitant release of $\mathrm{H}^{+}$. Tamura and Furuichi (1997), on the other hand, assumed that Mn(IV) ions on the surfaces of the Mn oxides

BGD

$8,273-321,2011$

\section{Manganese redox cycling in Lake Imandra \\ J. Ingri et al.}

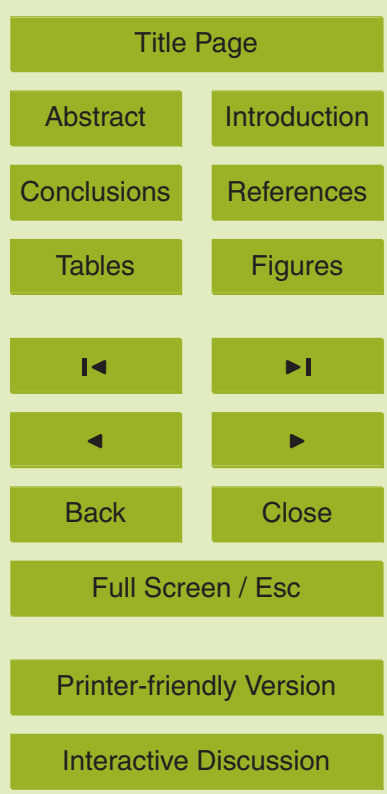


rapidly oxidize surrounding $\mathrm{Mn}(\mathrm{II})$ ions to $\mathrm{Mn}(\mathrm{III})$ ions, which in turn release $\mathrm{H}^{+}$upon hydrolysis. Since other divalent metal ions, such as $\mathrm{Ni}(\mathrm{II})$, compete for the same sites as the $\mathrm{Mn}(\mathrm{II})$ ions, they will be less efficiently adsorbed in the presence of high concentrations of $\mathrm{Mn}(\mathrm{II})$ ions. Close to the bottom $(0.1-1 \mathrm{~m})$, the concentration of $\mathrm{Mn}(\mathrm{II})$ 5 is higher than at $3 \mathrm{~m}$ depth above the sediment surface (Fig. 10). The resulting harder competition with $\mathrm{Mn}$ (II) ions close the bottom may thus account for the lower adsorption of $\mathrm{Ni}$ at this depth. The significantly higher concentration of particulate $\mathrm{Ni}$ in the bottom water (up to $180 \mathrm{mmol} \mathrm{kg}^{-1}$ ) compared to the Ni concentrations in the upper sediment $\left(20 \mathrm{mmol} \mathrm{kg}^{-1}\right)$ or the upper $20 \mathrm{~m}$ of the water column $\left(\approx 30 \mathrm{mmol} \mathrm{kg}^{-1}\right)$ indicates that 10 almost all adsorbed $\mathrm{Ni}$ associated with $\mathrm{Mn}$ oxides dissolves at the sediment-water interface (Fig. 10).

Sulphide phases (Balistrieri et al., 1992, 1994) and organic complexes (Viollier et al., 1995; Achterberg et al., 1997) have been suggested as important carriers of $\mathrm{Cu}$ in lakes, although Baccini and Joller (1981), Hamilton-Taylor et al. (1996), Green et 15 al. $(1989,2004)$ and Shacat et al. (2004) have observed an association between $\mathrm{Cu}$ and $\mathrm{Mn}$ and/or Fe oxides. Cu is less affected by the redox cycling of $\mathrm{Mn}$ compared with $\mathrm{Ni}$. There were small changes in the dissolved $\mathrm{Cu}$ concentration close to the bottom, although a flux of dissolved $\mathrm{Cu}$ across the sediment-water interface was indicated by the enhanced dissolved $\mathrm{Cu}$ concentrations in the sediment during winter stratification 20 in April (Fig. 12). Dissolved Cu showed enhanced concentration in the zone of $\mathrm{Mn}$ reduction at $2 \mathrm{~m}$ above the bottom, which points towards $\mathrm{Mn}$ particles for the distribution of $\mathrm{Cu}$ in bottom water in April. Analogous with the discussion above for $\mathrm{Ni}$, $\mathrm{Cu}$ shows a weaker adsorption to particulate Mn close to the sediment-water interface.

Despite significant enrichment of dissolved $\mathrm{Zn}$ in the porewater $(350 \mathrm{nM})$, there was 25 little flux of dissolved $\mathrm{Zn}$ to the bottom water (Fig. 12, Table 2). Most likely, the upward diffusing $\mathrm{Zn}$ is scavenged by precipitated Fe oxyhydroxides right below the sedimentwater interface. A peak in particulate $\mathrm{Zn}$ (Fig. 13) at $0.5 \mathrm{~cm}$ in the surface sediment supports this assumption. However, in the bottom water $\mathrm{Zn}$ showed correlations between dissolved and particulate Mn, with similar distributions as for Ni and $\mathrm{Cu}$ (Fig. 12).

\section{BGD}

8, 273-321, 2011

\section{Manganese redox cycling in Lake Imandra}

J. Ingri et al.

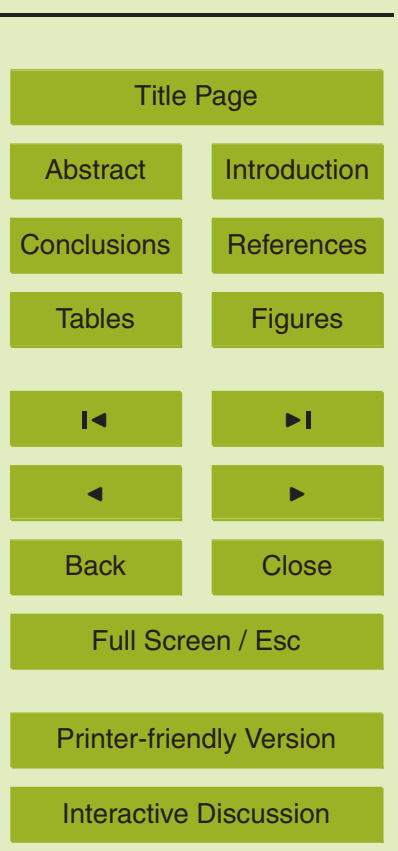


The $\mathrm{Zn} / \mathrm{Ti}$ ratio closely follows the $\mathrm{Mn} / \mathrm{Ti}$ ratio below $25 \mathrm{~m}$. Hence, $\mathrm{Zn}$ also appears to be related to the surface of the particulate Mn-rich phase.

BGD

\subsubsection{Ba and Mo cycling}

The alkaline earth element $\mathrm{Ba}$, similar to $\mathrm{Ni}, \mathrm{Cu}$ and $\mathrm{Zn}$ dominated by the dissolved divalent oxidation state in water, is correlated with $\mathrm{Mn}$ in Lake Imandra. Studies by Balistrieri et al. (1986), Sugiyama et al. (1992) and Falkner et al. (1997) all showed correlations between $\mathrm{Ba}$ and $\mathrm{Mn}$. In Lake Imandra, $\mathrm{Ba}$ and $\mathrm{Mo}$ are the trace elements that show the strongest linear correlation $\left(R^{2}\right.$ adjusted $\left.=0.95\right)$ with particulate $\mathrm{Mn}$ in the bottom water. In contrast to $\mathrm{Cu}, \mathrm{Ni}$ and $\mathrm{Zn}$ the $\mathrm{Ba} / \mathrm{Ti}$ ratio is highest close to the sediment water interface. A possible explanation is that $\mathrm{Ba}$ forms a phase (or inner sphere complex) with $\mathrm{Mn}$, and is therefore not mainly surface-enriched at the particulate Mn phase, while the associations of $\mathrm{Ni}, \mathrm{Cu}$ and $\mathrm{Zn}$ with $\mathrm{Mn}$ are more surface-related. Therefore, the concentration of $\mathrm{Ba}$ is less dependent on available surface area for adsorption and more dependent on the particulate $\mathrm{Mn}$ concentration than $\mathrm{Ni}, \mathrm{Cu}$ and $\mathrm{Zn}$.

Unlike $\mathrm{Ni}, \mathrm{Cu}, \mathrm{Zn}$ and $\mathrm{Ba}$, the most abundant species for Mo in aquatic environments is the anion $\mathrm{MoO}_{4}^{2-}$ (Wedepohl, 1978). Correlation between Mo and $\mathrm{Mn}$ has been reported by Balistrieri et al. (1994) and Magyar et al. (1993). In Lake Imandra, the distribution of particulate $\mathrm{Mo}$ in the bottom water is controlled by $\mathrm{Mn}$. The distribution pattern of particulate $\mathrm{Mo}$ and $\mathrm{Mo} / \mathrm{Ti}$ is similar to the profiles for $\mathrm{Ba}$ and $\mathrm{Ba} / \mathrm{Ti}$, respectively (Fig. 13). Along with $\mathrm{Ba}$, Mo is probably incorporated in the $\mathrm{Mn}$ phase.

\subsubsection{Cobolt cycling}

Santschi (1988), Green et al. (1989), Balistrieri et al. (1992) and Shacat et al. (2004) have suggested a coupling between $\mathrm{Co}$ and $\mathrm{Mn}$ in freshwater. Cobalt is strongly enriched in the suspended phase in the two samples close to the sediment-water interface (Fig. 12). Both the Co/Ti ratio and the particulate Co concentration show a much lower accumulation of $\mathrm{Co}$ in the $\mathrm{Mn}$ peak at $3 \mathrm{~m}$ from the sediment, compared with

\section{8, 273-321, 2011}

\section{Manganese redox cycling in Lake Imandra \\ J. Ingri et al.}

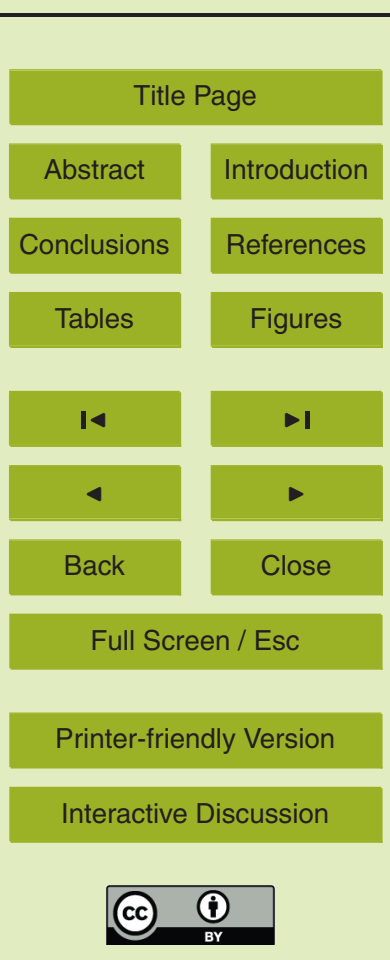


all the other Mn related elements (Fig. 13). It is likely that Co is associated with the Mn-rich phase (Stockdale et al., 2010), but in a different manner compared with $\mathrm{Cu}$, $\mathrm{Ni}, \mathrm{Zn}, \mathrm{Ba}$ and Mo. Cobalt is a redox element and can be oxidized to a trivalent state by the particulate Mn-surface (Murray and Dillard, 1979), and hence associated more 5 strongly to the Mn phase close to the sediment-water interface. Cobalt is therefore not as influenced by high activity of dissolved $\mathrm{Mn}^{2+}$ and can therefore be more strongly associated to the surface of the Mn-rich phase, close to the sediment-water interface.

\section{Fe-controlled cycling of As, Cd and Zn}

The influence of Fe on the mobility and cycling of As in aquatic systems is well estab10 lished. Arsenic is largely associated with Fe oxyhydroxides in oxic sediments and is released in the interstitial water when $\mathrm{Fe}(\mathrm{III})$ is reduced to $\mathrm{Fe}(\mathrm{II})$ upon burial of the sediment (Belzile, 1988; Belzile and Tesseir, 1990; Sauliner and Mucci, 2000; Bilali et al., 2002; Nicholas et al., 2003; Yang and Rose, 2005). In laboratory experiments where labile organic matter (plankton material) was added to oxic sediments, As was found to 15 be released to the water concurrently with Fe, after the reductive dissolution of $\mathrm{Mn}(\mathrm{IV})$ (Edenborn et al., 1986). For $\mathrm{Cd}$ and $\mathrm{Zn}$, the cycling of organic matter has been proposed to play a key role in controlling distributions of these metals in surface sediments (Martin et al., 2001; Bilali et al., 2002; Nameroff et al., 2002, Yang and Rose, 2005). In zone $\mathrm{V}$ the particulate As, $\mathrm{Cd}$ and $\mathrm{Zn}$ show enrichments immediately below sediment surace and depletion at $1.5 \mathrm{~cm}$. This pattern is most likely related to the redox cycling of Fe. The redox boundary for $\mathrm{Fe}(\mathrm{II})$ to $\mathrm{Fe}(\mathrm{III})$ is situated in the upper $1 \mathrm{~cm}$ of the sediment, with intense dissolution of Fe oxyhydroxides at $1.5 \mathrm{~cm}$ and re-precipitation right below sediment-water interface. The enrichment of $\mathrm{As}, \mathrm{Cd}$ and, to some minor extent, of $\mathrm{Zn}$ in the sulphide zone (IV) is most likely controlled by a sulphide-associated

\section{BGD}

8, 273-321, 2011

\section{Manganese redox cycling in Lake Imandra}

J. Ingri et al.

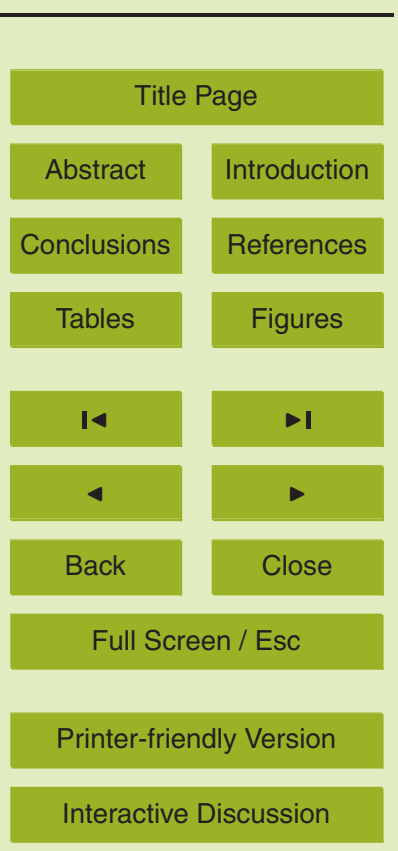


2001). For example, in the sulphide production zones of two mine-impacted Canadian Shield lakes (Clearwater and Chevreuil) formation of authigenic greenockite (CdS), wurtzite (Zn,Fe)S and am-ZnS were observed, while As was found adsorbed onto, or substituted into, Fe monosulphides (Huerta-Diaz et al., 1998). The distribution of As 5 is a mirror image of the Fe/S ratio in the sulphide zone (Fig. 6e), strongly suggesting a close relation between As and Fe sulphides.

\section{Summary}

Distribution of the trace metals in zone $\mathrm{V}$ (upper $2 \mathrm{~cm}$ of the sediment) can be classified into three groups. Mo, Cu and Ni form one group (1), characterized by decreased con10 centrations in the top $2 \mathrm{~cm}$ and a small peak at $2.5 \mathrm{~cm}$. The second group (2) consists of As, Cd and $\mathrm{Zn}$. This group exhibits a clear enrichment in the top $1 \mathrm{~cm}$. Ba, Co and $\mathrm{Pb}$ forms the third group (3), characterized by almost constant metal concentrations in the upper $6 \mathrm{~cm}$ of the sediment column. The redox cycle of $\mathrm{Mn}$ in the bottom water and in the top $2 \mathrm{~cm}$ primarily controls distribution of group-one metals ( $\mathrm{Cu}$, Ni and $\mathrm{Mo}$ ), while 15 the precipitation of Fe oxyhydroxides below the sediment surface cause the enrichment of group-two metals (As, Cd and $\mathrm{Zn}$ ) in the surface sediment. The distribution of Ba, $\mathrm{Co}$ and $\mathrm{Pb}$ in the upper $6 \mathrm{~cm}$ is primarily controlled by mineral apatite-rich material.

\section{References}

Achterberg, E. P., van den Berg, C. M., Boussemart, M., and Davison, W.: Speciation and cycling of trace elements in Esthwaite Water: a productive English lake with seasonal deepwater anoxia, Geochim. Cosmochim. Ac., 61, 5233-5253, 1997.

Aller, R. C., Hall, P. O. J., Rude, P. D., and Aller, J. Y.: Biogeochemical heterogeneity and suboxic diagenesis in hemipelagic sediments of the Panama Basin, Deep-Sea Res., 45, 133-165, 1998.

25 Anschutz, P., Sundby, B., Lefrançois, L., Luther III, G. W., and Mucci, A.: Interactions between

\section{BGD}

$8,273-321,2011$

\section{Manganese redox cycling in Lake Imandra}

J. Ingri et al.

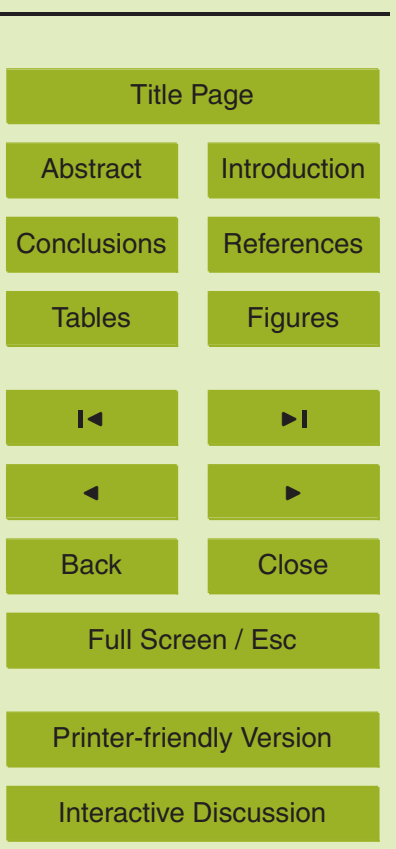


metal oxides and species of nitrogen and iodine in bioturbated marine sediments, Geochim. Cosmochim. Ac., 64, 2751-2763, 2000.

Baccini, P. and Joller, T.: Transport processes of copper and zinc in a highly eutrophic and meromictic lake, Schweiz. Z. Hydrol., 43, 176-199, 1981.

5 Balistrieri, L. S. and Murray, J. W.: The surface chemistry $\delta \mathrm{MnO}_{2}$ in major ion seawater, Geochim. Cosmochim. Ac., 46, 1041-1052, 1982.

Balistrieri, L. S. and Murray, J. W.: The surface chemistry of sediments from the Panama Basin: the influence of manganese oxides on metal adsorption, Geochim. Cosmochim. Ac., 50, 235-243, 1986.

10 Balistrieri, L. S., Murray, J. W., and Paul, B.: The cycling of iron and manganese in the water column of Lake Sammamish, Washington, Limnol. Oceanogr., 37, 510-528, 1992.

Balistrieri, L. S., Murray, J. W., and Paul, B.: The geochemical cycling of trace elements in a biogenic meromictic lake, Geochim. Cosmochim. Ac., 58, 3993-4008, 1994.

Belzile, N.: The fate of arsenic in sediments of the Laurentian Trough, Geochim. Cosmochim.

15 Ac., 52, 2293-2302, 1988.

Belzile, N. and Tessier, A.: Interactions between arsenic and iron oxyhydroxides in lacustrine sediments, Geochim. Cosmochim. Ac., 54, 103-109, 1990.

Belzile, N., Chena, Y.-W., Gunn, J. M., and Dixit, S. S.: Sediment trace metal profiles in lakes of Killarney Park, Canada: from regional to continental influence, Environ. Pollut., 130, 239248, 2004.

Benz, M., Brune, A., and Schink, B.: Anaerobic and aerobic oxidation of ferrous iron at neutral $\mathrm{pH}$ by chemoheterotrophic nitrate reducing bacteria, Arch. Microbiol., 169, 159-165, 1998.

Bilali, L. E., Rasmussen, P. E., Hall, G. E. M., and Fortin, D.: Role of sediment composition in trace metal distribution in lake sediments, Appl. Geochem., 17, 1171-1181, 2002.

Birch, L., Hanselmann, K. W., and Bachofen, R.: Heavy metal conservation in Lake Cadagno sediments: historical records of anthropogenic emissions in a meromictic alpine lake, Water Res., 30, 679-687, 1996.

Blomqvist, S. and Abrahamsson, B.: An improved Kajak-type gravity core sampler for soft bottom sediments, Schweiz. Z. Hydrol., 47, 81-84, 1985.

so Brown, E. T., Callonnec, L. L., and German, C. R.: Geochemical cycling of redox-sensitive metals in sediments from Lake Malawi: A diagnostic paleotracer for episodic changes in mixing depth, Geochim. Cosmochim. Ac., 64, 3515-3523, 2000.

Burman, J.-O., Pontér, C., and Boström, K.: Metaborate digestion procedure for inductively

BGD

$8,273-321,2011$

\section{Manganese redox cycling in Lake Imandra}

J. Ingri et al.

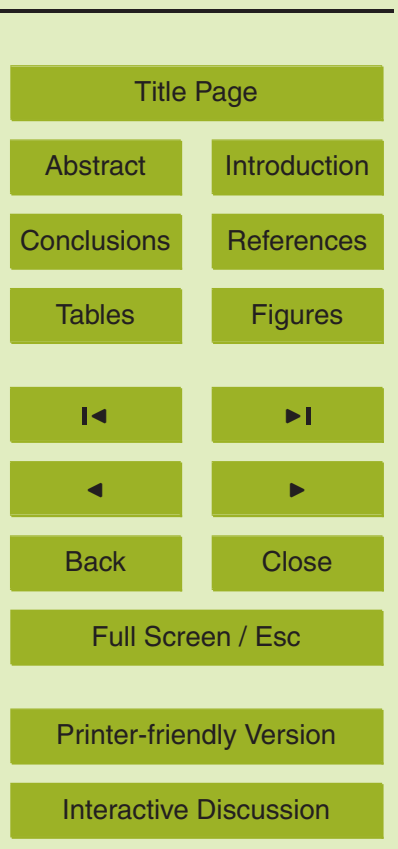


coupled plasma optical emission spectrometry, Anal. Chem., 50, 679-680, 1978.

Canfield, D. E., Green, W. J., and Nixon, P.: Pb-210 and stable Pb through the redox transition zone of an Antarctic lake, Geochim. Cosmochim. Ac., 59, 2459-2468, 1995.

Dalsgaard, T., Thamdrup, B., and Canfield, D. E.: Anaerobic ammonium oxidation (anammox) in the marine environment, Res. Microbiol., 156, 457-464, 2005.

Dauvalter, V. A., Moiseenko, T. I., Kudryavtseva, L. P., and Sandimirov, S. S.: Accumulation of heavy metals in Lake Imandra because of its pollution with industrial waste, Water Res., 27, 279-287, 2000.

Davison, W.: Iron and manganese in lakes, Earth-Sci. Rev., 34, 119-163, 1993.

Douglas, G. and Adeney, J.: Diagenetic cycling of trace elements in the bottom sediments of the Swan River Estuary, Western Australia, Appl. Geochem., 15, 551-566, 2000.

De Carlo, E. H. and Green, W. J.: Rare earth elements in the water column of Lake Vanda, McMurdo Dry Valleys, Antarctica, Geochim. Cosmochim. Ac., 66, 1323-1333, 2002.

Edenborn, H. M., Belzile, N., Mucci, A., Lebel, J., and Silverberg, N.: Observations on the 15 diagenetic behavior of arsenic in a deep coastal sediment, Biogeochemistry, 2, 359-376, 1986.

Friedl, G., Wehrli, B., and Manceau, A.: Solid phases in the cycling of manganese in eutrophic lakes: new insights from EXAFS spectroscopy, Geochim. Cosmochim. Ac., 61, 275-290, 1997.

20 Falkner, K. K., Church, M., Measures, C. I., LeBaron, G., Thouron, D., Jeandel, C., Stordal, M. C., Gill, G. A., Mortlock, R., Froelich, P., and Chan, L.-H.: Minor and trace element chemistry of Lake Baikal, its tributaries, and surrounding hot springs, Limnol. Oceanogr., 42, 329-345, 1997.

Froelich, P. N., Klinkhammer, G. P., Bender, M. L., Luedtke, N. A., Heath, G. R., Cullen, D., Dauphin, P., Hammond, D., Hartman, B., and Maynard, V.: Early oxidation of organic matter in pelagic sediments of the Eastern Equatorial Atlantic: suboxic diagenesis, Geochim. Cosmochim. Ac., 43, 1075-1090, 1979.

Green, W. J., Ferdelman, T. G., and Canfield, D. E.: Metal dynamics in Lake Vanda (Wright Valley, Antarctica), Chem. Geol., 76, 85-94, 1989.

30 Green, W. J., Canfield, D. E., and Nixon, P.: Cobalt cycling and fate in Lake Vanda, in: Lakes of the McMurdo Dry Valleys, edited by: Priscu, J., American Geophysical Union, 1998.

Green, J. W., Stage, B. R., Bratina, B. J., Wagers, S., Preston, A., O'Bryan, K., Shacat, J., and Newell, S.: Nickel, copper, zinc and cadmium cycling with manganese in Lake Vanda (Wright

\section{BGD}

$8,273-321,2011$

\section{Manganese redox \\ cycling in Lake Imandra}

J. Ingri et al.

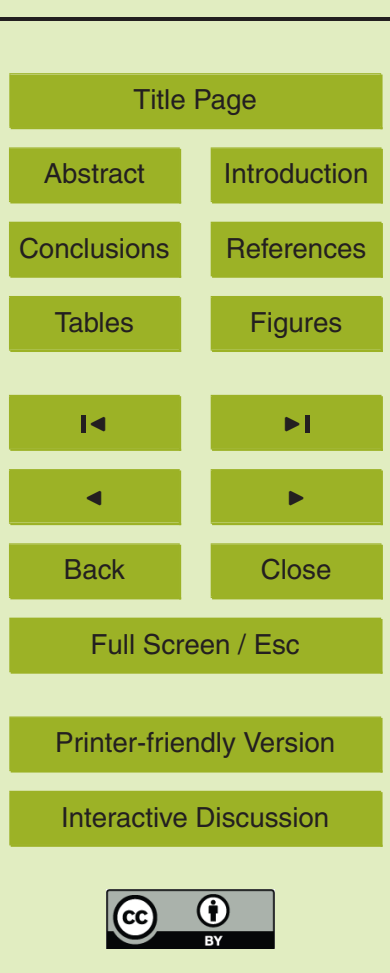


Valley, Antarctica), Aquat. Geochem., 10, 303-323, 2004.

Hafenbradl, D., Keller, M., Dirmeier, R., Rachel, R., Rossnagel, P., Burggraf, S., Huber, H., and Stetter, K. O.: Ferroglobus placidus gen. nov., sp. nov., a novel hyperthermophilic archaeum that oxidizes $\mathrm{Fe}^{2+}$ at neutral $\mathrm{pH}$ under anoxic conditions, Arch. Microbiol., 166, 308-314, 1996.

Hamilton-Taylor, J. and Davison, W.: Redox-driven cycling of trace elements in lakes, in: Physics and Chemistry of Lakes, edited by: Lerman, A., Gat, J. R., and Imboden, D. M., 2nd ed., Springer Verlag, Heidelberg, 217-263, 1995.

Hamilton-Taylor, J., Davison, W., and Morfett, K.: The biogeochemical cycling of $\mathrm{Zn}, \mathrm{Cu}, \mathrm{Fe}$, $10 \mathrm{Mn}$, and dissolved organic $\mathrm{C}$ in a seasonally anoxic lake, Limnol. Oceanogr., 41, 408-418, 1996.

Huerta-Diaz, M. A., Tessier, A., and Carignan, R.: Geochemistry of trace metals associated with reduced sulfur in freshwater sediments, Appl. Geochem., 13, 213-233, 1998.

Hulth, S., Aller, R. C., Canfield, D. E., Dalsgaard, T., Engström, P., Gilberte, F., Sundbäck, K., and Thamdrup, B.: Nitrogen removal in marine environments: recent findings and future research challenges, Mar. Chem., 94, 125-145, 2005.

Hulth, S., Aller, R. C., and Gilbert, F.: Coupled anoxic nitrification/ manganese reduction in marine sediments, Geochim. Cosmochim. Ac., 63, 49-66, 1999.

Jørgensen, B. B. and Nelson D. C.: Sulfide oxidation in marine sediments; geochemistry 20 meets biology, in: Sulfur Biogeochemistry, Past and Present, edited by: Amend, J. P., Edwards, K. J., and Lyons, T. W., Special Paper, The Geological society of America, 63-81, 2004.

Konovalov, S., Samodurov, A., Oguz, T., and Ivanov, L.: Parameterization of iron and manganese cycling in the Black Sea suboxic and anoxic environment, Deep-Sea Res. Pt. I, 51, 2027-2045, 2004.

Luther III, G. W., Sundby, B., Lewis, B. L., Brendel, P. J., and Silverberg, N.: Interactions of manganese with the nitrogen cycle: alternative pathways to dinitrogen, Geochim. Cosmochim. Ac., 61, 4043-4052, 1997.

Magyar, B., Moor, H. C., and Sigg, L.: Vertical distribution and transport of molybdenum in a lake with a seasonally anoxic hypolimnion, Limnol. Oceanogr., 38, 521-531, 1993.

Martin, A. J., McNee, J. J., and Pedersen, T. F.: The reactivity of sediments impacted by metal mining in Lago Junin, Peru, J. Geochem. Explor., 74, 175-187, 2001.

Moiseenko, T. I. and Yakovlev, V. A.: Anthropogenic Modifications of Aquatic Systems of the

BGD

8, 273-321, 2011

\section{Manganese redox \\ cycling in Lake Imandra}

J. Ingri et al.

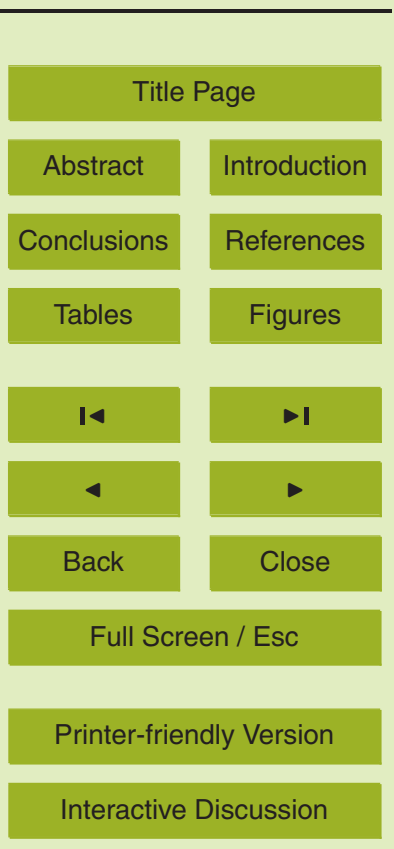


Kola Arctic, Leningrad, Nauka, 224 pp., 1990. (in Russian)

Moiseenko, T. I., Dauvalter, V. A., and Rodushkin, I.: Geochemical migration and covariation of elements in the Lake Imandra, Barents Region, Research report 1996:22, Luleå University of Technology, 1996.

5 Moiseenko, T. I., Dauvalter, V. A., Lukin, A. A., Kudryavtseva, L. P., lliachshuk, B. P., Iliachshuk, L. I., Sandimirov, S. S., Kagan, L., Vandysh, O. I., Sharov, A. N., Sharova, U. N., and Koroleva, I. N.: Anthropogenic Modification of Lake Imandra Ecosystem, Moscow, Nauka, 403 pp., 2002. (in Russian)

Morgan, J. J. and Stumm, W.: Colloid-chemical properties of manganese dioxide, J. Coll. Sci. Imp. U. Tok., 19, 347-359, 1964.

Morse, J. W. and Luther III, G. W.: Chemical influences on trace metal-sulfide interactions in anoxic sediments, Geochim. Cosmochim. Ac., 63, 3373-3378, 1999.

Mucci, A.: Manganese uptake during calcite precipitation from seawater: conditions leading to formation of pseudokutnahorite, Geochim. Cosmochim. Ac., 61, 2023-2036, 1988.

Murray, J. W.: Mechanisms controlling the distribution of trace elements in oceans and lakes, in: Sources and Fates of Aquatic Pollutants, edited by: Hites, R. A. and Eisenreich, S. J., Am. Chem. Soc., 1987.

Murray, J. W. and Dillard, J. G.: The oxidation of cobalt(II) adsorbed on manganese dioxide, Geochim. Cosmochim. Ac., 43, 781-787, 1979.

20 Murray, J. W., Codispoti, L. A., and Friederich, G. E.: The suboxic zone in the Black Sea, in: Aquatic Chemistry: Interfacial and Interspecies Processes, edited by: Huang, C. P., O'Melia, C. R., and Morgan, J. J., ACS Advances in Chemistry Series, vol. 244, 157-176, 1995.

Nriagu, J. O., Lawson, G., Wong, H. K. T., and Cheam, V.: Dissolved trace metals in Lakes 25 Superior, Erie and Ontario, Environ. Sci. Technol., 30, 178-187, 1996.

Nameroff, T. J., Balistrieri, L. S., and Murray, J. W.: Suboxic trace metal geochemistry in the Eastern Tropical North Pacific, Geochim. Cosmochim. Ac., 66, 1139-1158, 2002.

Neal, A., Techkarnjanaruk, S., Dohnalkova, A., McCready, D., Peyton, B., and Geesey, G.: Iron sulfides and sulfur species produced at hematite surfaces in the presence of sulfate-reducing 30 bacteria, Geochim. Cosmochim. Ac., 65, 223-23, 2001.

Naylor, C., Davison, W., Motelica-Heino, M., Van Den Berg, G. A., and Van Der Heijdt, G. A.: Simultaneous release of sulfide with $\mathrm{Fe}, \mathrm{Mn}, \mathrm{Ni}$ and $\mathrm{Zn}$ in marine harbour sediment measured using a combined metal/sulfide DGT probe, Sci. Total Environ., 328, 275-286, 2004.

\section{BGD}

$8,273-321,2011$

\section{Manganese redox \\ cycling in Lake Imandra}

J. Ingri et al.

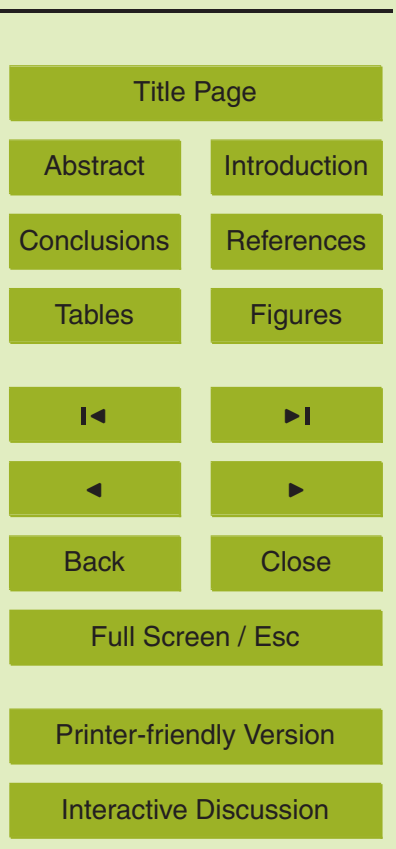


Nicholas, D. R., Ramamoorthy, S., Palace, V., Spring, S., and Moore, F.: Biogeochemical transformations of arsenic in circumneutral freshwater sediments, Biodegradation, 14, 123-137, 2003.

Ödman, F., Ruth, T., and Pontér, C.: Validation of a field filtration technique for characterization of suspended particulate matter from freshwater, Part I: Major elements, Appl. Geochem., 14, 1-17, 1999.

Oguz, T., Murray, J. W., and Callahan, A.: Modeling redox cycling across the suboxic-anoxic interface zone in the Black Sea, Deep-Sea Res., 48, 761-787, 2001.

Otero, X. L., Huerta-Diaz, M. A., and Macias, F.: Influence of a turbidite deposit on the extent of pyritization of iron, manganese and trace metals in sediments from the Guaymas Basin, Gulf of California (Mexico), Appl. Geochem., 18, 1149-1163, 2003.

Petkov, V., Ren, Y., Saratovsky, I., Pasten, P., Gurr, S., Hayward, M., Poeppelmeier, K., and Gaillard, J. F.: Atomic-scale structure of biogenic materials by total x-ray diffraction: a study of bacterial and fungal $\mathrm{MnO}_{2}$, ACS Nano, 3, 441-445, 2009.

Posselt, H. S., Andersson, F. J., and Weber, W. J.: Cation sorption on colloidal hydrous manganese dioxide, Environ. Sci. Technol., 2, 1087-1093, 1968.

Reimers, C. E., Jahnke, R. A., and McCorkle, M.: Carbon fluxes and burial rates over the continental slope and rise off central California with implications for the global carbon cycle, Global Biogeochem. Cy., 6, 199-224, 1992.

20 Salomons, W., De Rooij, N. M., Kerdijk, H., and Bril, J.: Sediments as a source for contaminants? Hydrobiologia, 147, 13-30, 1987.

Saulnier, I. and Mucci, A.: Trace metal remobilization following the resuspension of estuarine sediments: Saguenay Fjord, Canada, Appl. Geochem., 15, 191-210, 2000.

Santschi, P. H.: Factors controlling the biogeochemical cycles of trace elements in fresh and coastal marine waters as revealed by artificial radiotracers, Limnol. Oceanogr., 33, 848-866, 1988.

Shacat, J. A., Green, W. J., Decarlo, E. H., and Newell, S.: The geochemistry of Lake Joyce, McMurdo Dry Valleys, Antarctica, Aquat. Geochem., 10, 325-352, 2004.

Sholkovitz, E. R. and Copland, D.: The chemistry of suspended matter in Esthwaite Water, 30 a biologically productive lake with seasonally anoxic hypolimnion, Geochim. Cosmochim. Ac., 46, 393-410, 1982.

Stockdale, A., Davison, W., Zhang, H., and Hamilton-Taylor, J.: The assiciation of cobalt with iron and manganese (oxyhyd)oxides in marine sediment, Aquat. Geochem., 16, 575-585,
BGD

$8,273-321,2011$

\section{Manganese redox \\ cycling in Lake Imandra}

J. Ingri et al.

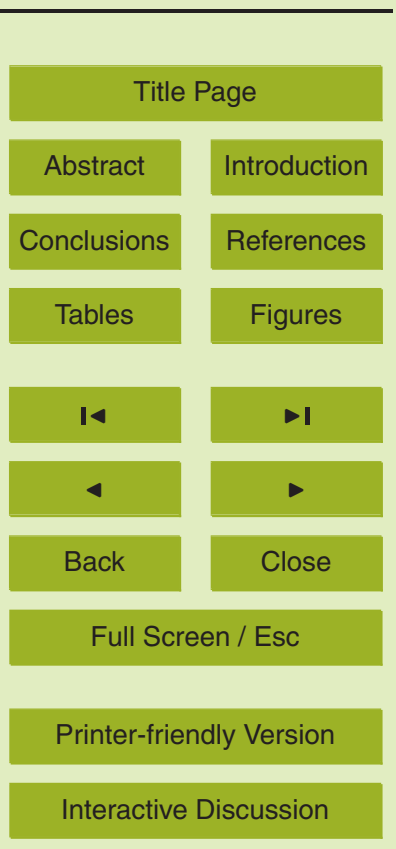


Sugiyama, M., Hori, T., Kihara, S., and Matsui, M.: A geochemical study on the specific distribution of barium in Lake Biwa, Japan, Geochim. Cosmochim. Ac., 56, 597-605, 1992.

Tamura, H. and Furuichi, R.: Adsorption affinity of divalent heavy metal ions for metal oxides evaluated by modeling with the Frumkin isotherm, J. Colloid Interf. Sci., 195, 241-249, 1997.

Taylor, S. R. and McLennan, S. M.: The Continental Crust: Its Composition and Evolution, Blackwell Scientific Publ., Oxford, England, 1985.

Tebo, B. M.: Manganese(II) oxidation in the suboxic zone of the Black Sea, Deep-Sea Res., 38, 883-905, 1991.

10 Viollier, E., Jézéquel, D., Michard, G., Pèpe, M., Sarazin, G., and Albéric, P.: Geochemical study of a crater lake (Pavin Lake, France): trace-element behaviour in the monimolimnion, Chem. Geol., 125, 61-72, 1995.

Wedepohl, K. H.: Handbook of Geochemistry, Vol. II/4, Springer-Verlag, 1978.

Williams, T. M.: Diagenetic metal profiles in recent sediments of a Scottish freshwater loch, Environ. Geol. Water Sci., 20, 117-123, 1992.

Yang, $\mathrm{H}$. and Rose, N.: Trace element pollution records in some UK lake sediments, their history, influence factors and regional differences, Environ. Int., 31, 63-75, 2005.

Yang, H., Rose, N. L., and Battarbee, R. W.: Distribution of some trace metals in Lochnagar, a Scottish mountain lake ecosystem and its sediment, Sci. Total Environ., 285, 197-208, 2002.

BGD

8, 273-321, 2011

\section{Manganese redox cycling in Lake Imandra}

J. Ingri et al.

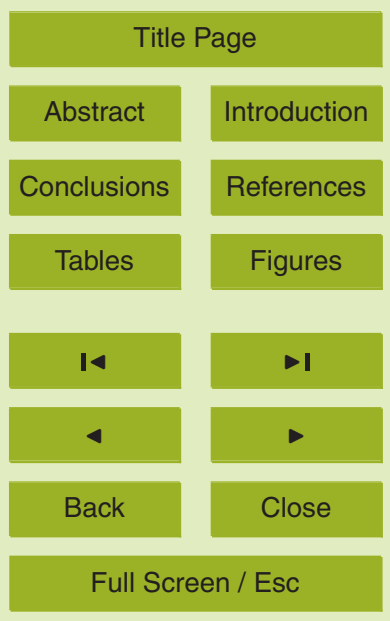

Printer-friendly Version

Interactive Discussion 
BGD

8, 273-321, 2011

\section{Manganese redox cycling in Lake Imandra}

J. Ingri et al.

Title Page

Abstract

Introduction

Sampling station

and concentration

天父 Kirovsk

Babinskaya

Imandra

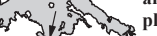

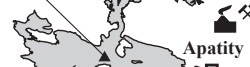

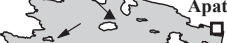

Imandra

$\begin{array}{lll}0 \quad 5 & 10 \mathrm{~km}\end{array}$

River Niva

Fig. 1. Lake Imandra and the location of the sampling station and the main pollution sources. The arrows indicate the major flow of water towards the outflow of Imandra Lake, the River Niva.

\section{Full Screen / Esc}

\section{Figures}

$\rightarrow 1$

Close
Printer-friendly Version

Interactive Discussion 
BGD

8, 273-321, 2011

\section{Manganese redox cycling in Lake Imandra}

J. Ingri et al.

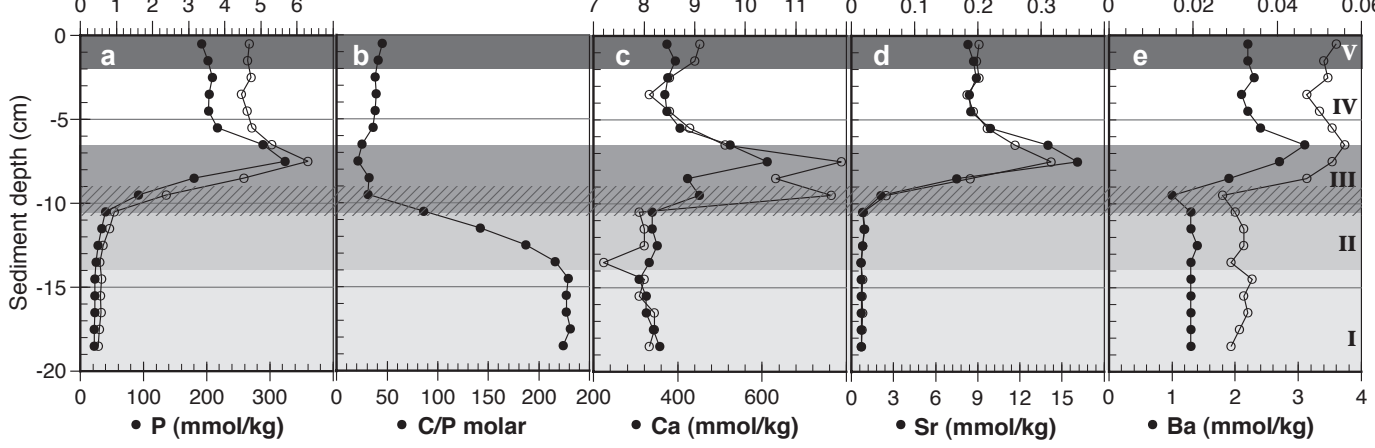

Fig. 2. Sediment profiles for the elements related mainly to the apatite mining. Ti-normalized values are shown by unfilled dots. Zones within the sediment column: I. Pre-industrial period, before 1930; II. Early industrial period, 1930-1955; III. Industrial expansion period with no treatment facilities or recirculation systems, 1955-1975; IV. Zone of active secondary sulphide formation; V. Zone of manganese dissolution and iron precipitation.

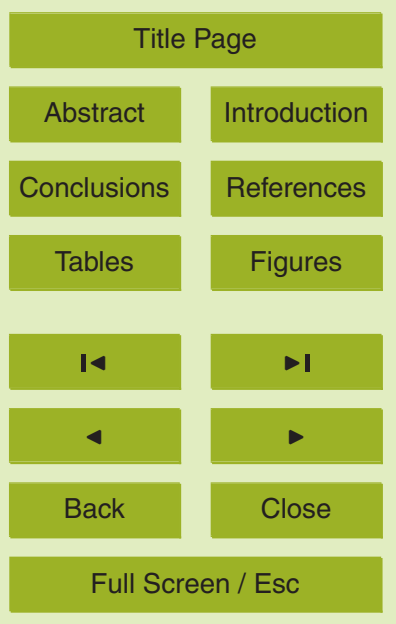

Printer-friendly Version

Interactive Discussion 
BGD

$8,273-321,2011$

\section{Manganese redox cycling in Lake Imandra}

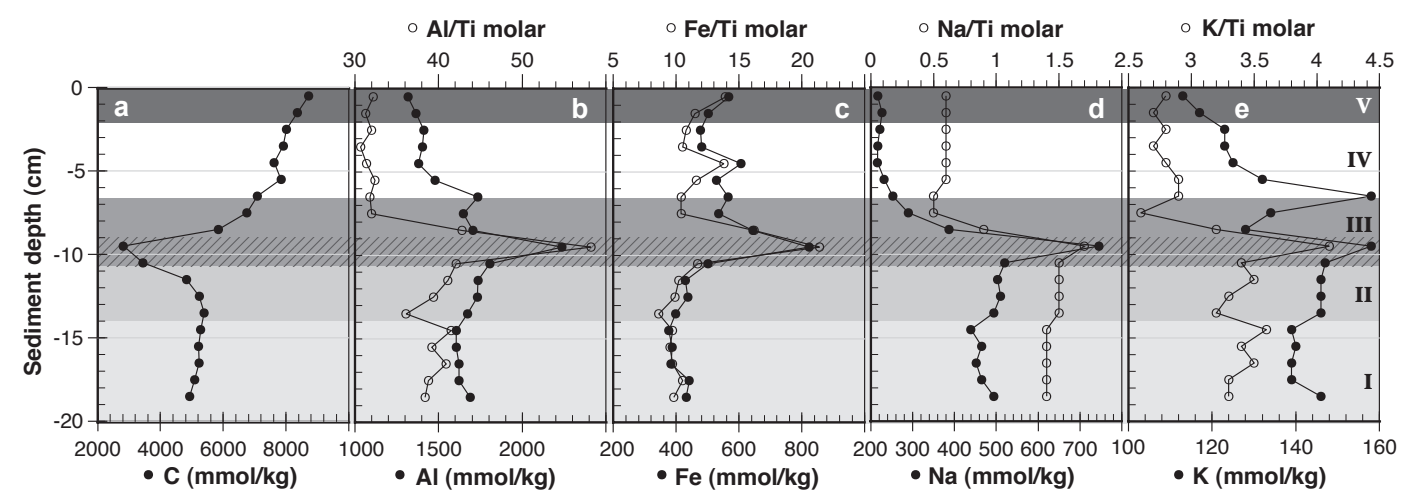

Fig. 3. Sediment profiles for the major elements influenced by the industrial activities. Tinormalized metal values are shown by unfilled dots. Transient peaks of $\mathrm{Al}, \mathrm{Fe}, \mathrm{Na}$ and $\mathrm{K}$ betwwen 10.5 and $9 \mathrm{~cm}$ (marked by hatch pattern) within zone III reflect the influx of particulate material possibly linked to the construction of a series of large setting dams and the start of new open pits at the apatite complex between 1955-1965.
J. Ingri et al.

\section{Title Page}

\section{Abstract}

Introduction

Conclusions

References

Tables

Figures

14

4

Back

Close

\section{Full Screen / Esc}

Printer-friendly Version

Interactive Discussion 


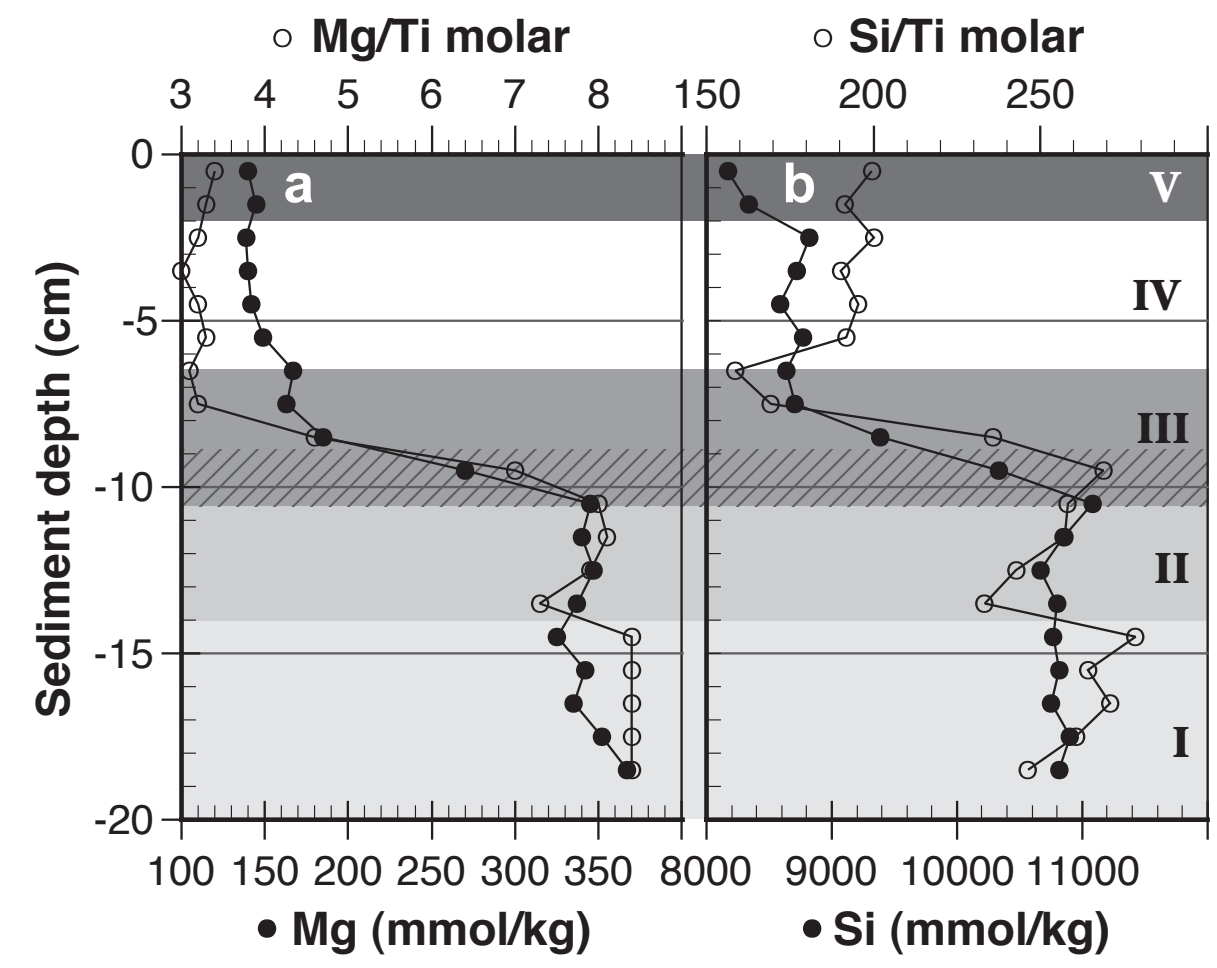

Fig. 4. Sediment profiles for Mg and Si. Ti-normalized metal values are shown by unfilled dots.
BGD

$8,273-321,2011$

Manganese redox cycling in Lake Imandra

J. Ingri et al.

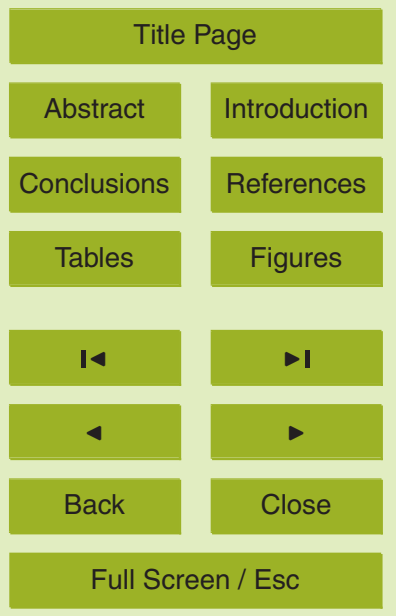

Printer-friendly Version

Interactive Discussion 


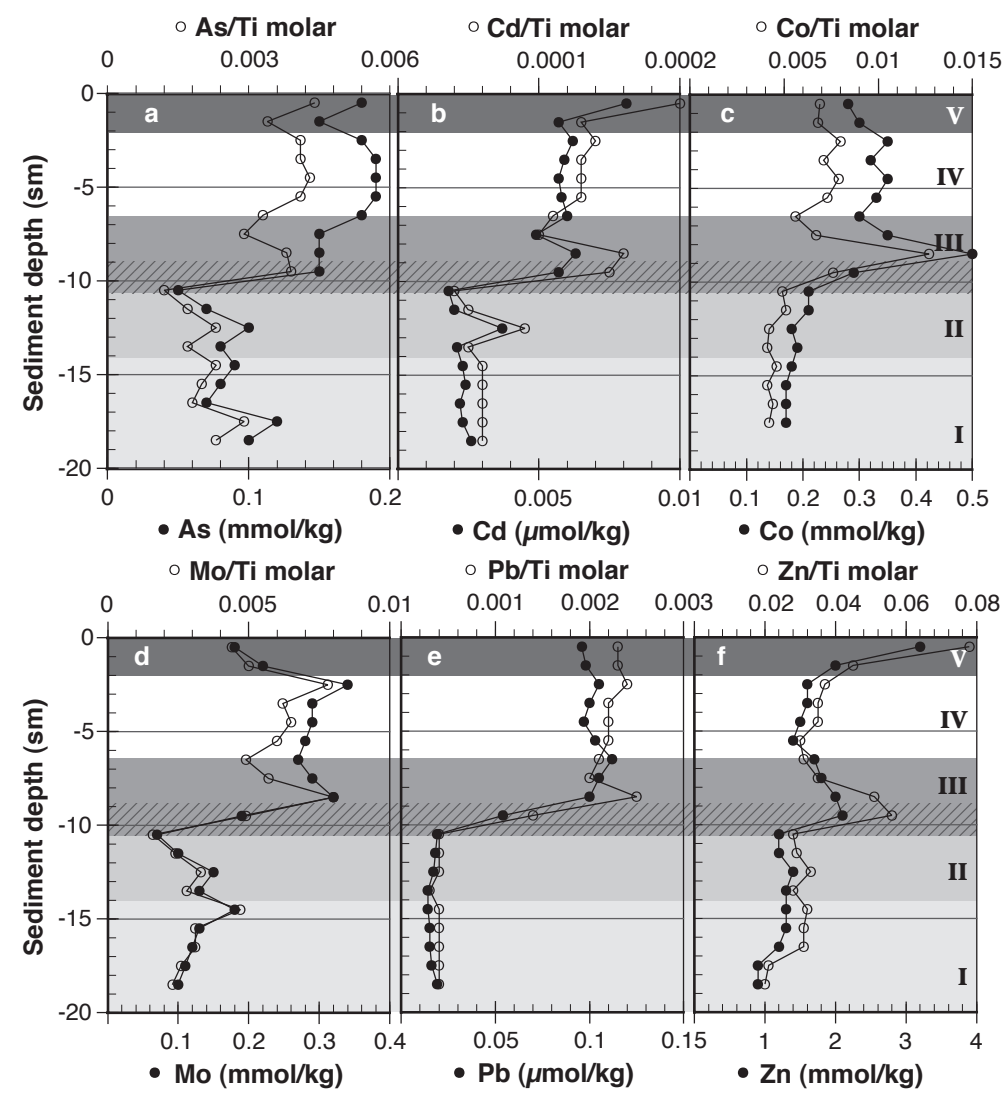

BGD

8, 273-321, 2011

\section{Manganese redox cycling in Lake Imandra}

J. Ingri et al.

\section{Title Page}

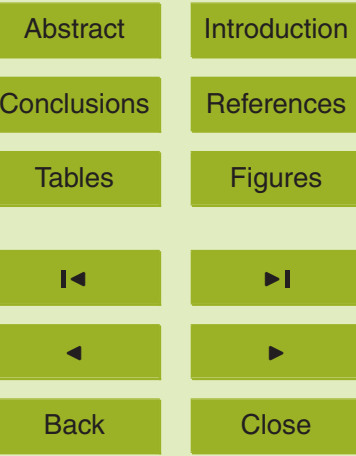

\section{Full Screen / Esc}

Printer-friendly Version

Fig. 5. Sediment profiles for selected trace metals (a) As, (b) Cd, (c) Co, (d) Mo, (e) Pb and (f) Zn. Ti-normalized values are shown by unfilled dots.

Interactive Discussion 
BGD

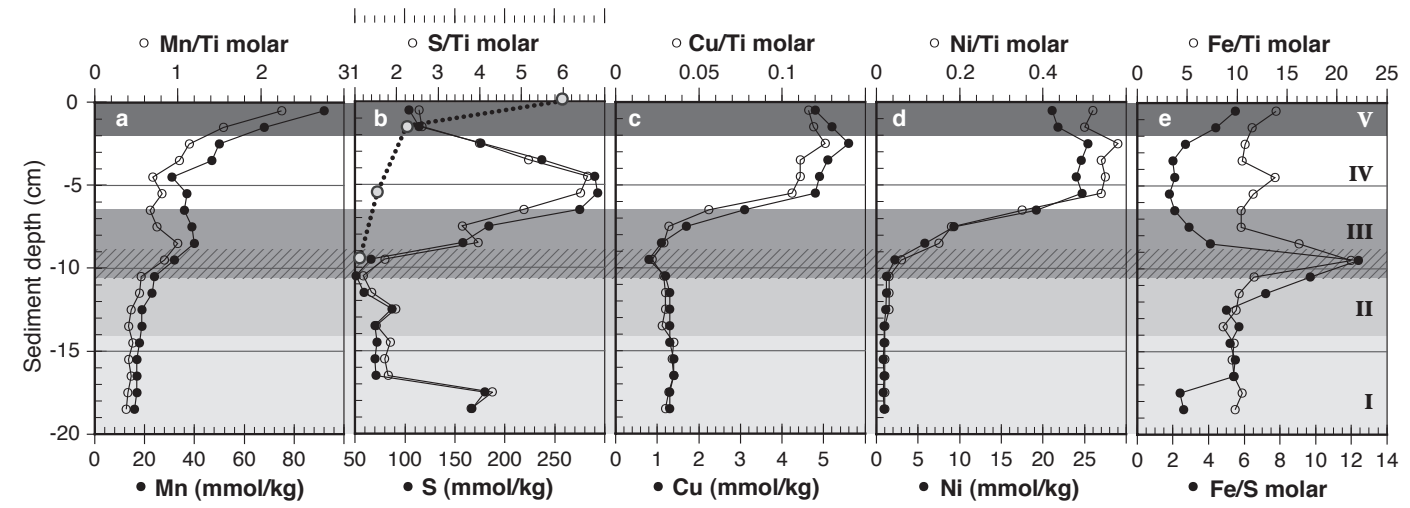

Fig. 6. Sediment profiles for (a) particulate $M n$, (b) particulate $S$ and pore water sulphate, (c) $\mathrm{Cu}, 8 \mathrm{~d}) \mathrm{Ni}$ and (e) particulate Fe/S molar. Ti-normalized values are marked with unfilled dots.

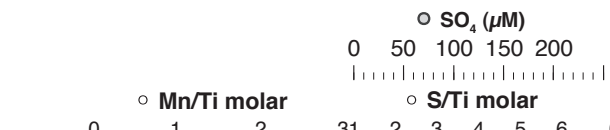

8, 273-321, 2011

\section{Manganese redox cycling in Lake Imandra}

J. Ingri et al.

J. Ingietal.

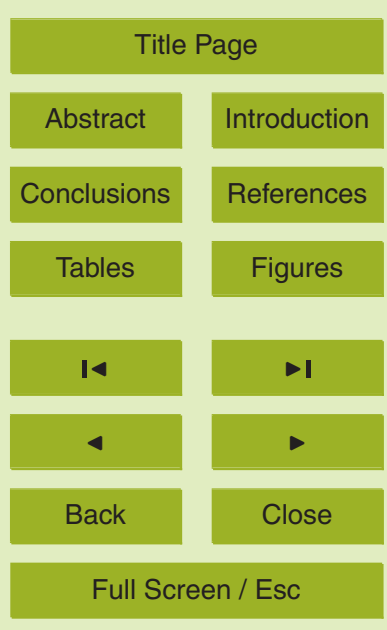

Printer-friendly Version

Interactive Discussion 


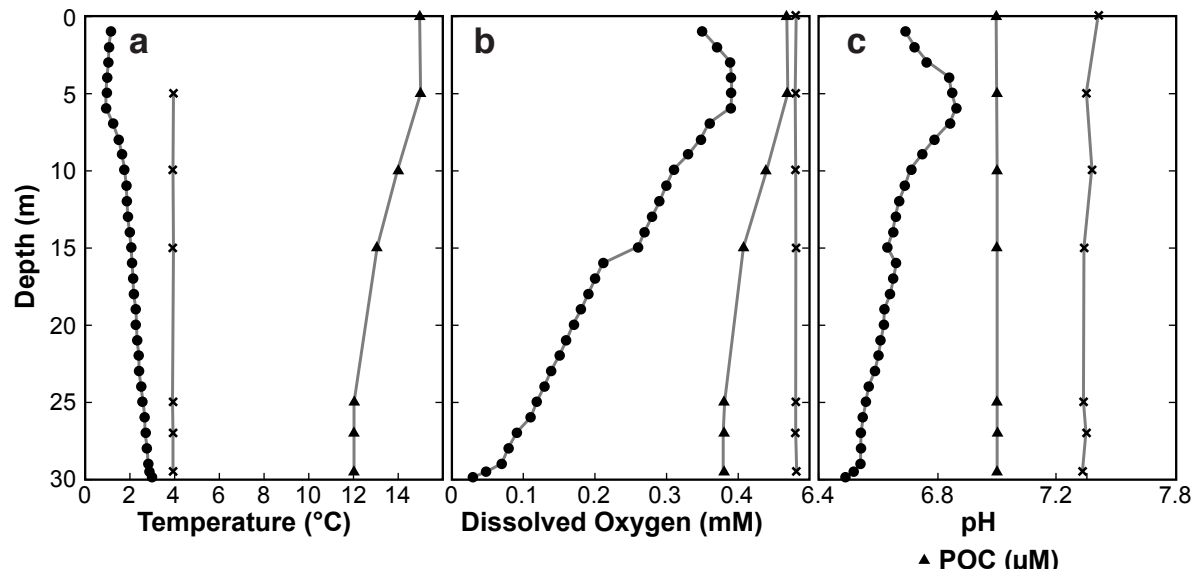

BGD

\section{8, 273-321, 2011}

\section{Manganese redox} cycling in Lake Imandra

J. Ingri et al.

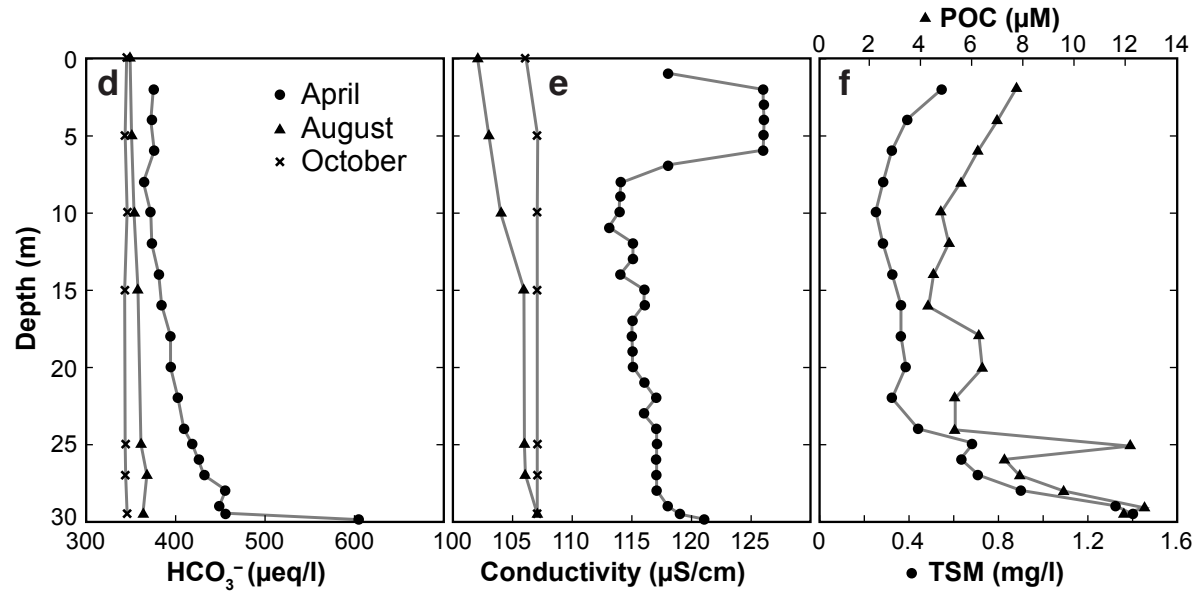

\section{Title Page}

Abstract

Introduction

Conclusions

References

Tables

Figures

14

$>$ I

4

Back

Close

\section{Full Screen / Esc}

Printer-friendly Version

Fig. 7. Profiles of (a) water temperature, (b) dissolved oxygen, (c) $\mathrm{pH}$, (d) alkalinity and (e) conductivity in April (dot), August (triangle) and October (cross). (f) total suspended matter (TSM) and particulate organic carbon (POC) in April. 
BGD

8, 273-321, 2011

\section{Manganese redox cycling in Lake} Imandra
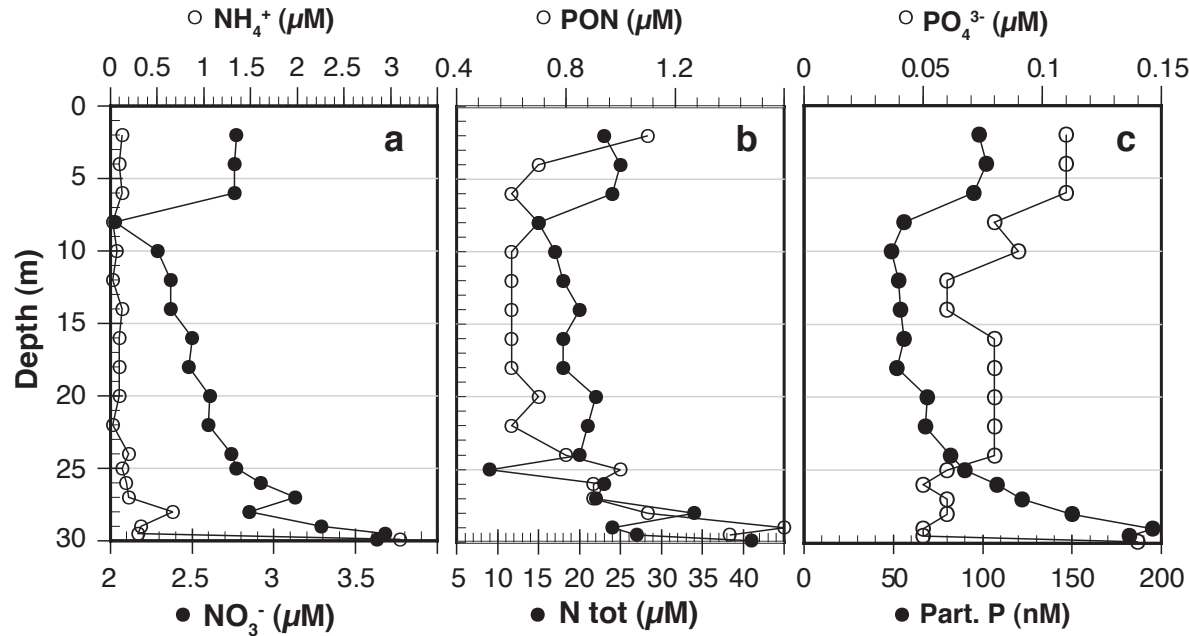

Fig. 8. Profiles of (a) dissolved nitrate and ammonium (b) total nitrogen and particulate organic nitrogen and (c) particulate phosphorous and phosphate in Lake Imandra in April.

\section{J. Ingri et al.}

\section{Title Page}

\section{Abstract}

Introduction

Conclusions

References

Tables

Figures

I

$\rightarrow 1$

4

Back

Close

\section{Full Screen / Esc}

Printer-friendly Version

Interactive Discussion 
BGD

8, 273-321, 2011
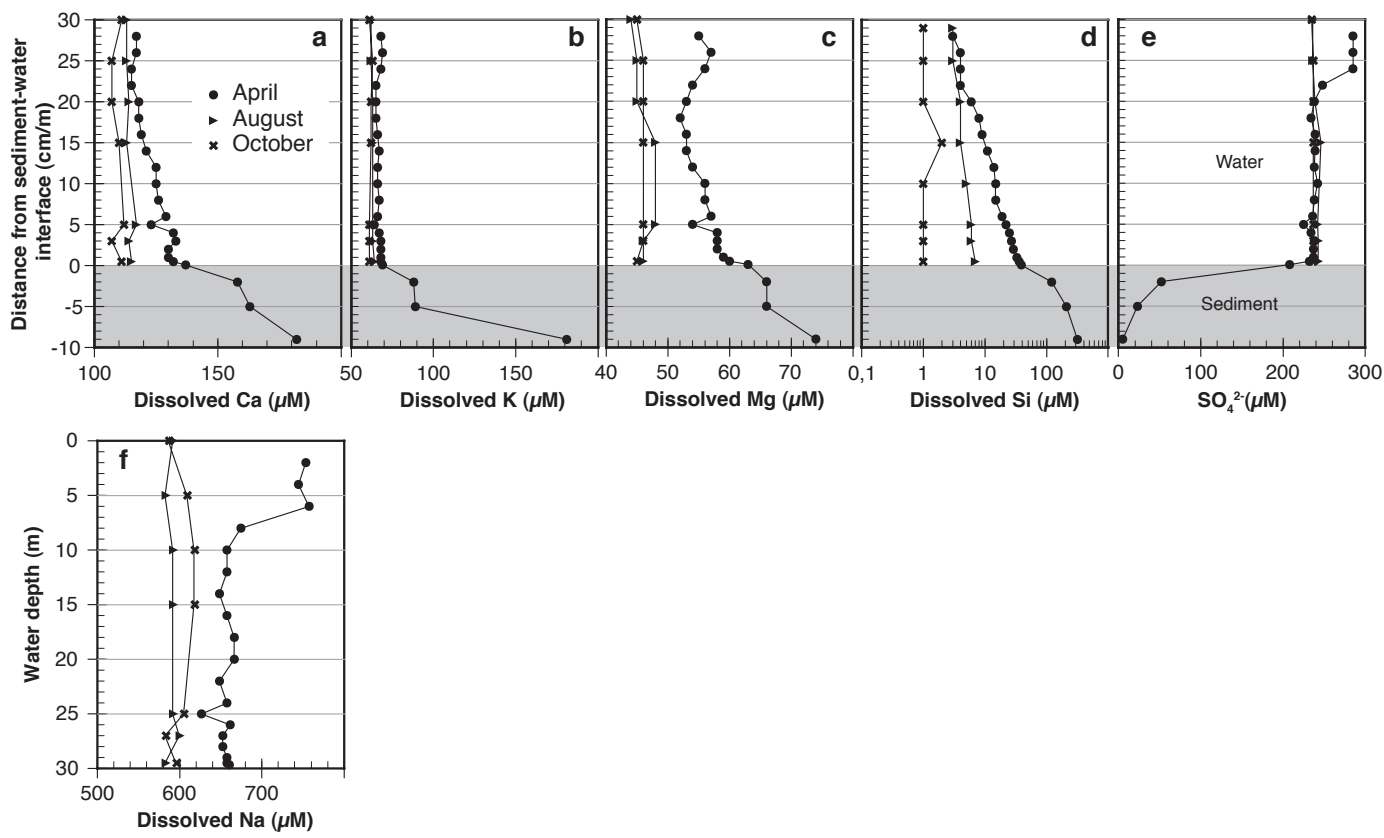

Fig. 9. Concentrations of dissolved major elements in April (dots), August (triangles) and October (crosses).

\section{Manganese redox cycling in Lake Imandra \\ J. Ingri et al.}

\section{Title Page}

\section{Abstract}

Introduction

Conclusions

References

Tables

Figures

14

4

Back

Close

\section{Full Screen / Esc}

Printer-friendly Version

Interactive Discussion 

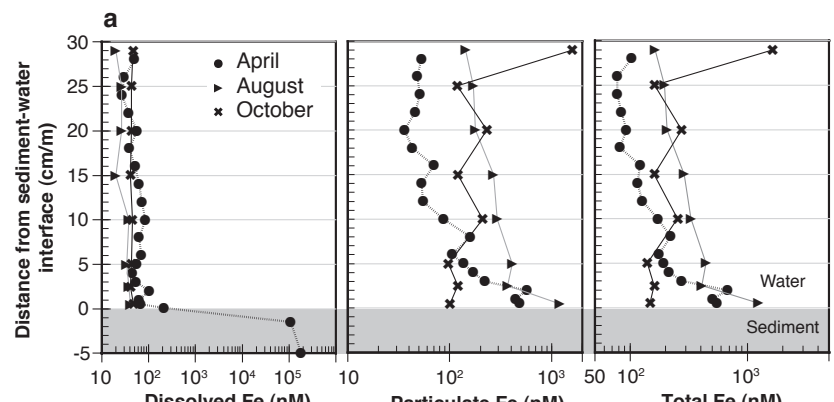

BGD

8, 273-321, 2011
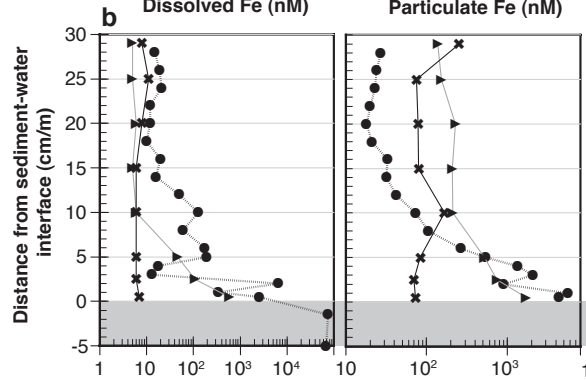

Total Fe (nM)

\section{Manganese redox cycling in Lake Imandra}

J. Ingri et al.

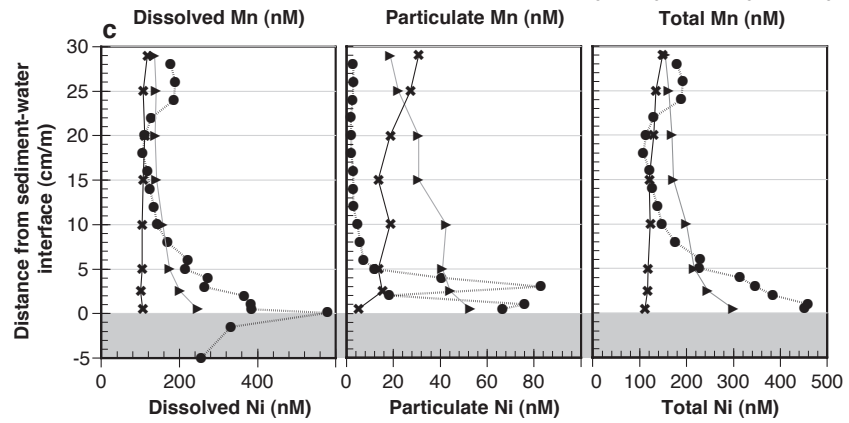

\section{Title Page}

Abstract

Conclusions

\section{Tables}

14

4

\section{Back}

\section{Full Screen / Esc}

Printer-friendly Version

Interactive Discussion
Fig. 10. Distribution of dissolved, particulate and total $\mathrm{Fe}$ (a), $\mathrm{Mn}$ (b) and $\mathrm{Ni}$ (c) in the water column and sediment (dissolved only). Note the log scales. 


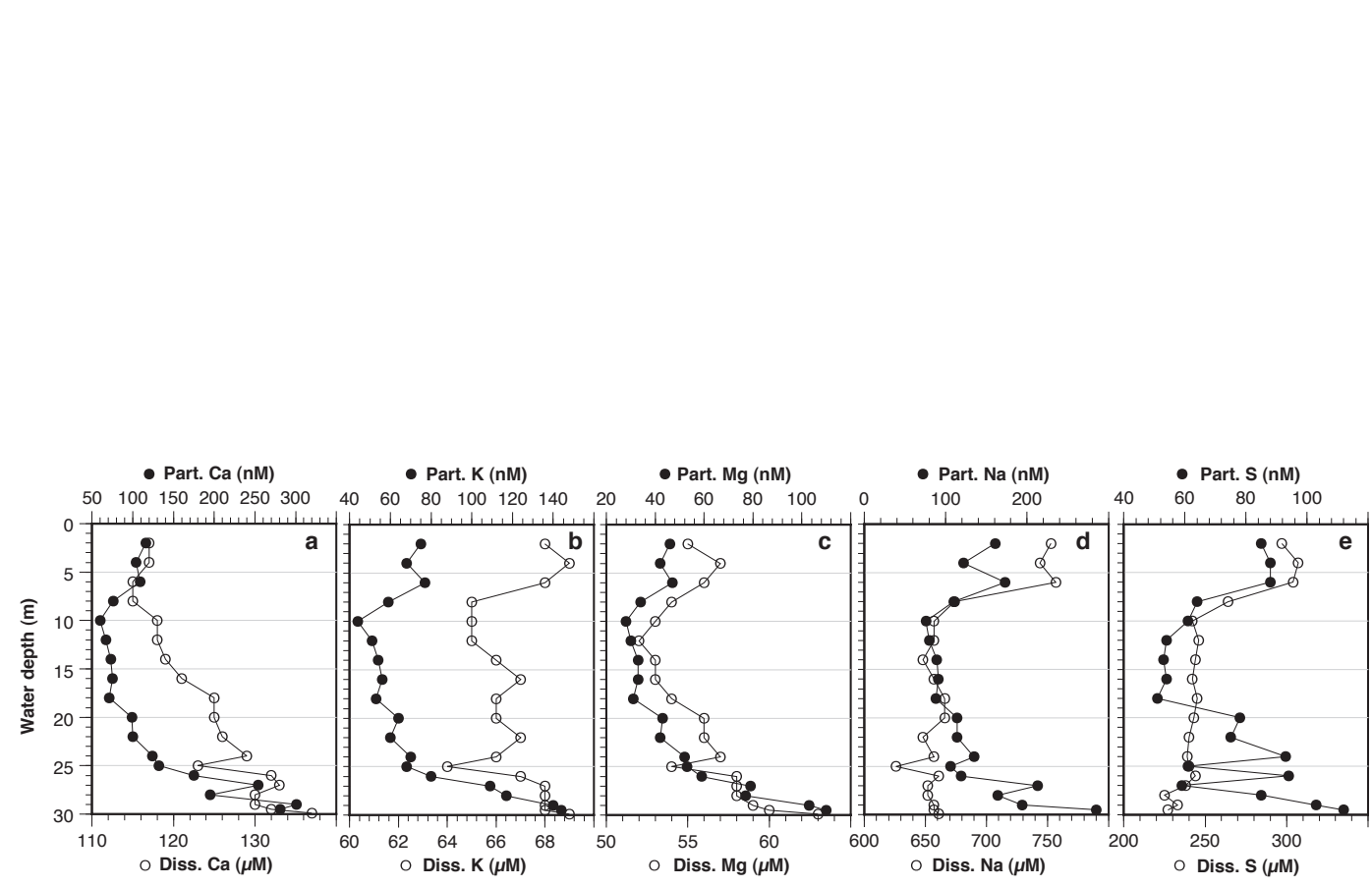

BGD

8, 273-321, 2011

\section{Manganese redox cycling in Lake Imandra}

J. Ingri et al.

\section{Title Page}

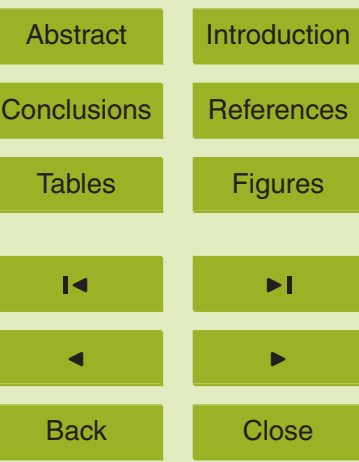

Full Screen / Esc

Printer-friendly Version

Interactive Discussion 

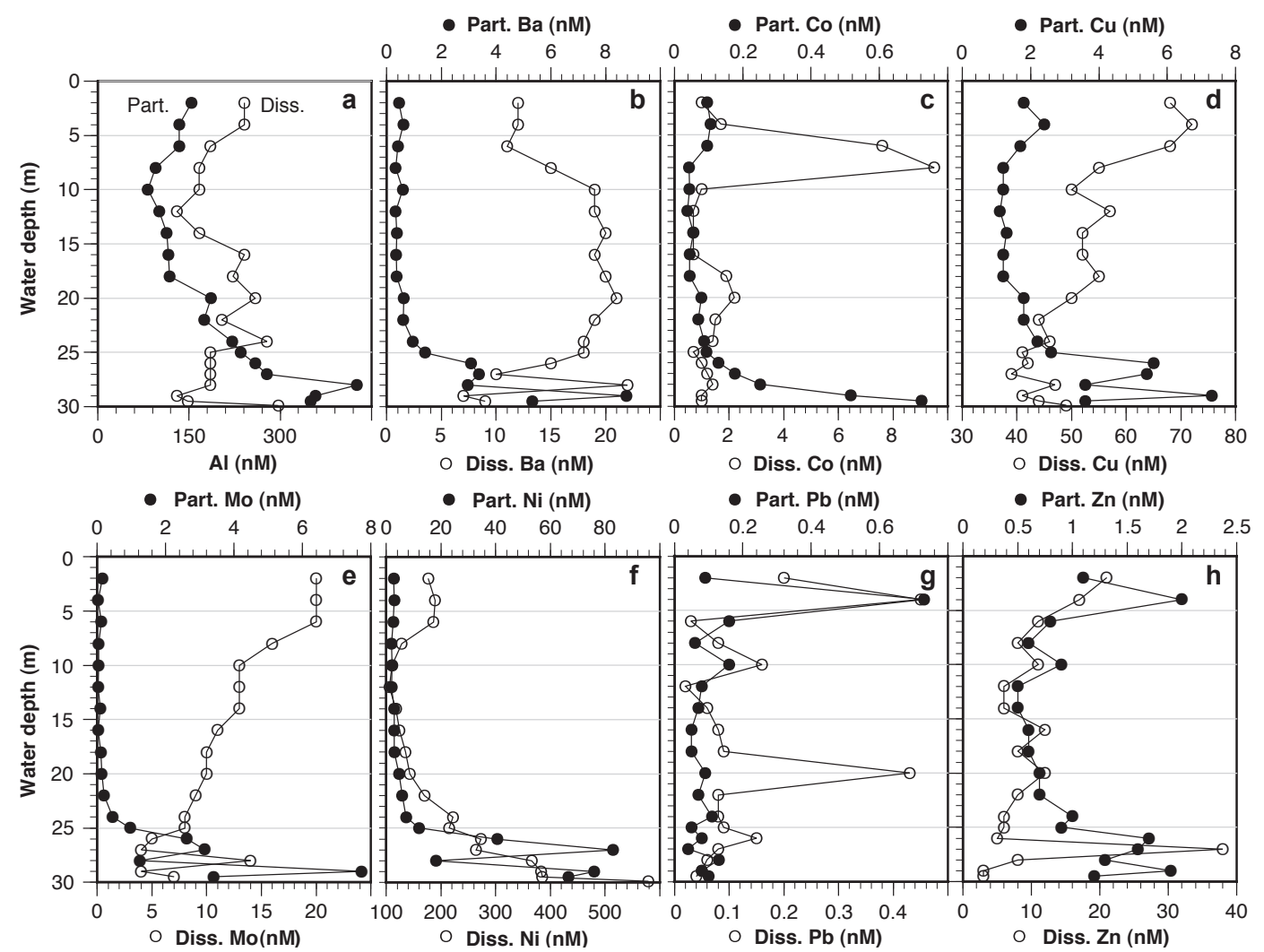

- Part. Ni (nM)

- Part. Pb (nM)
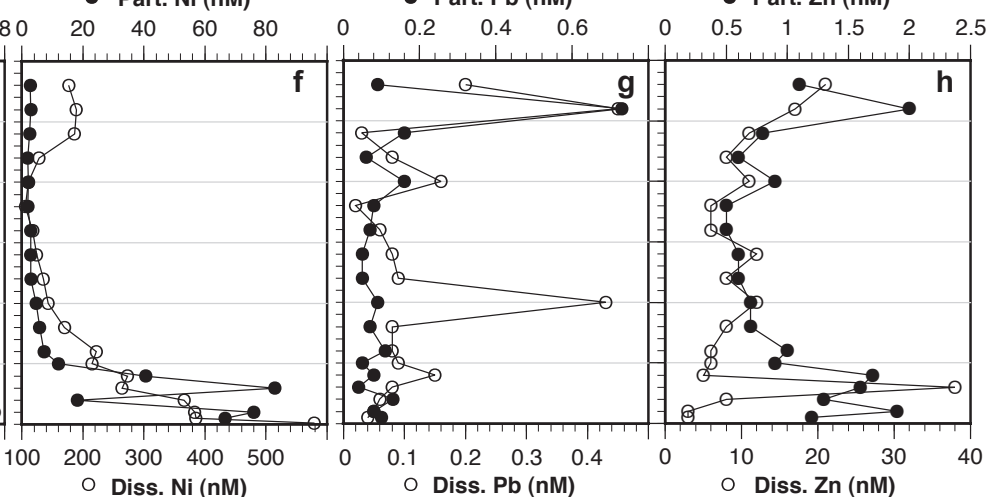

Fig. 12. Profiles of dissolved and particulate trace metals in April.
BGD

$8,273-321,2011$

\section{Manganese redox cycling in Lake Imandra}

J. Ingri et al.

\section{Title Page}

Abstract

Introduction

Conclusions

References

Tables

Figures

14

$\rightarrow$ I

4

Back

Close

\section{Full Screen / Esc}

Printer-friendly Version

Interactive Discussion 


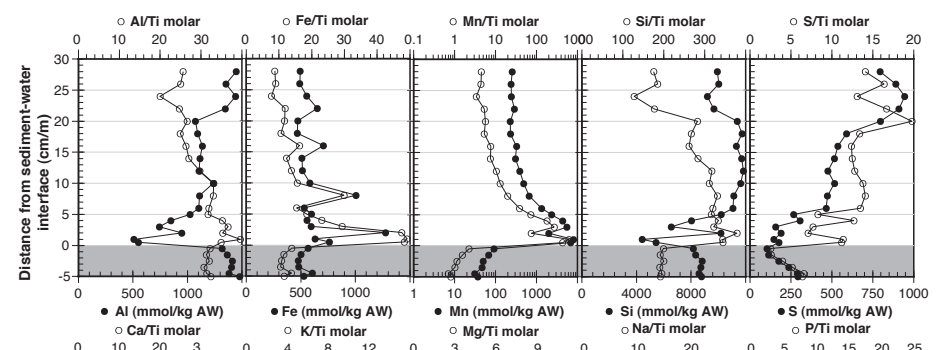

BGD

8, 273-321, 2011
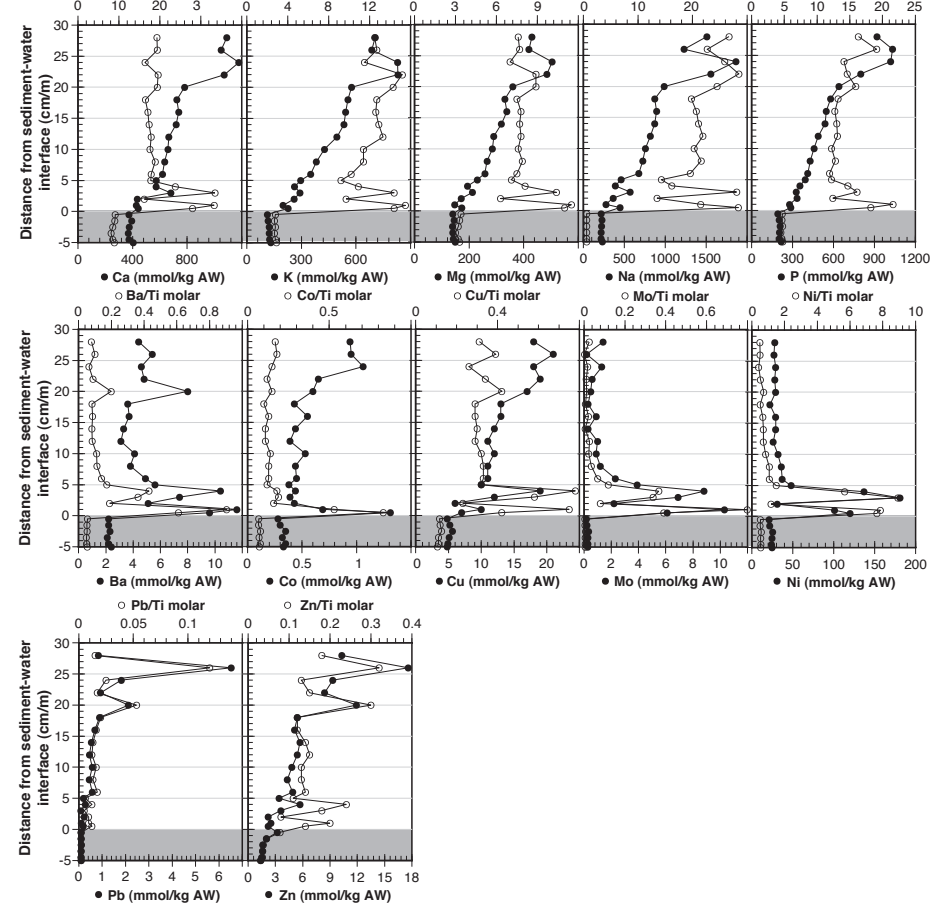

\section{Manganese redox cycling in Lake Imandra}

J. Ingri et al.

Title Page

Abstract

Conclusions

Tables

14

4

Back
Introduction

References

Figures

$>$ I

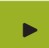

Close

\section{Full Screen / Esc}

Printer-friendly Version

Interactive Discussion

Fig. 13. Particulate ( $\mathrm{mmol} / \mathrm{kg}$ ashed weight) major and trace element concentrations in the water column and surface sediment in April. Ti-normalized values are shown by unfilled dots. 